\title{
PENGARUH MODAL KERJA TERHADAP RENTABILITAS PADA PT. BUKIT AGUNG SEHATI PALEMBANG
}

\author{
Endang Sri Mulatsih \\ Dosen STIE Mulia Darma Pratama
}

\begin{abstract}
ABSTRAK
Penelitian ini menguji Pengaruh Pengaruh Modal Kerja Terhadap Rentabilitas Pada PT. Bukit Agung Sehati Palembang. Tujuan dari penelitian ini adalah Untuk mengetahui modal kerja mempunyai pengaruh terhadap rentabilitas pada PT. Bukit Agung Sehati Palembang selama periode 2015-2019. Metode Penelitian dengan menggunakan Obyek Penelitian yang dilakukan di PT. Bukit Agung Sehati Palembang yang beralamat di Jalan Padat Karya Rt.4 No.18 Kelurahan Talang Buluh Kecamatan Talang Kelapa Kabupaten Banyuasin. Di mana Ruang lingkup penelitian adalah Modal Kerja terhadap kinerja keuangan di PT. Bukit Agung Sehati Palembang, laporan keuangan yaitu Neraca dan Rugi- laba. Dari hasil perhitungan maka dapat dibentuk persamaan regresi yaitu :

$\mathrm{Y}=0,315+0,019 \mathrm{X}$ Hasil yang didapat dari analisis regresi sederhanan dengan mengunakan alat SPSS versi 22 menunjukkan bahwa ada pengaruh dari Modal Kerja Terhadap Rentabilitas Pada PT. Bukit Agung Sehati Palembang.
\end{abstract}

Kata Kunci: Modal Kerja, Rentabilitas

\section{PENDAHULUAN}

\subsection{Latar Belakang}

Dalam menghadapi krisis finansial

yang terjadi sekarang ini, sebuah perusahaan ataupun lembaga usaha baik milik pemerintah maupun swasta dituntut untuk lebih memaksimalkan kinerjanya dalam berbagai hal terutama dalam hal memperoleh laba karena pada umumnya suatu perusahaan didirikan dengan tujuan untuk memperoleh laba atau keuntungan yang semaksimal mungkin demi menjamin kelangsungan hidup perusahaan tersebut agar tetap bertahan sampai masa yang akan datang. Untuk mencapai tujuan tersebut, sangat diperlukan adanya kerjasama yang baik antara manajer bersama para karyawannya dalam memanfaatkan dan mengelola sumbersumber dana yang ada dalam lingkungan perusahaan tersebut secara efisien dan efektif.

Besarnya jumlah laba yang dicapai oleh suatu perusahaan bukanlah merupakan suatu jaminan atau ukuran bahwa suatu perusahaan tersebut telah memanfaatkan sumber dana yang ada secara efektif, melainkan masih ada faktor lain yang ikut mempengaruhi. Faktor lain tersebut adalah perbandingan antara laba yang diperoleh dengan jumlah seluiruh modal yang digunakan untuk meghasilkan laba tersebut 
yang dinamakan dengan rentabilitas. Dengan demikian, yang harus diperhatikan oleh perusahaan adalah tidak hanya bagaimana usaha untuk memperbesar laba, tetapi yang lebih penting adalah usaha untuk mempertinggi rentabilitasnya oleh sebab itu, perusahaan lebih berusaha untuk mendapatkan titik rentabilitas maksimal dari pada laba maksimal.Dalam menjalankan perusahaan, manajer perusahaan tidak akan terlepas dari permodalan perusahaan yaitu pemenuhan modal kerja maupun investasi. Apabila perusahaan telah mencapai posisi tertentu dapat melakukan ekspansi atau perluasan usaha. Dalam melakukan ekspansi, suatu perusahaan tidak akan terlepas dari kebutuhan akan modal. Pemenuhan kebutuhan modal tersebut dapat dilakukan dengan berbagai cara, antara lain dengan modal sendiri yang terdiri dari saldo laba, modal dari pemegang saham dan dari sumber lainnya yaitu modal pinjaman atau dapat pula diperoleh dengan mengkombinasikan keduanya.

Modal kerja merupakan masalah pokok dan topik penting yang sering kali dihadapi oleh perusahaan, karena hampir semua perhatian untuk mengelola modal kerja dan aktiva lancar yang merupakan bagian yang cukup besar dari aktiva. Modal kerja dibutuhkan oleh setiap perusahaan untuk membelanjai operasinya sehari-hari, misalnya: untuk memberikan persekot pembelian bahan mentah, membiayai upah gaji pegawai, dan lain-lain, dimana uang atau dana yang dikeluarkan tersebut diharapkan dapat kembali lagi masuk dalam perusahaan dalam waktu singkat melalui hasil penjualan produksinya. Oleh karena itu, perusahaan dituntut untuk selalu meningkatkan efisiensi kerjanya sehingga dicapai tujuan yang diharapkan oleh perusahaan yaitu mencapai laba yang optimal. Pengelolaan modal kerja merupakan hal yang sangat penting dalam perusahaan, karena meliputi pengambilan keputusan mengenai jumlah dan komposisi aktiva lancar dan bagaimana membiayai aktiva ini. Perusahaan yang tidak dapat memperhitungkan tingkat modal kerja yang memuaskan, maka perusahaan kemungkinan mengalami insolvency (tak mampu memenuhi kewajiban jatuh tempo) dan bahkan mungkin terpaksa harus dilikuidasi. Aktiva lancar harus cukup besar untuk dapat menutup hutang lancar sedemikian rupa, sehingga menggambarkan adanya tingkat keamanan (margin safety) yang memuaskan. Sementara itu, jika perusahaan menetapkan modal kerja yang berlebih akan menyebabkan perusahaan overlikuid sehingga menimbulkan dana menganggur yang akan mengakibatkan inefisiensi perusahaan, dan membuang kesempatan memperoleh laba.

Dalam penentuan kebijakan modal kerja yang efisien, perusahaan dihadapkan pada masalah adanya kinerja keuangan (Van Horne, 2016: 217). Jika perusahaan memutuskan menetapkan modal kerja dalam jumlah yang besar, kemungkinan tingkat kinerja keuangan akan terjaga namun kesempatan untuk memperoleh laba yang besar akan menurun yang pada akhirnya berdampak pada menurunnya kinerja keuangan. Sebaliknya jika perusahaan ingin memaksimalkan tingkat kinerja keuangan, kemungkinan dapat mempengaruhi tingkat kinerja perusahaan. Makin tinggi kinerrja keuangan, maka makin baiklah posisi perusahaan di mata kreditur. Oleh karena terdapat kemungkinan yang lebih besar bahwa perusahaan akan dapat membayar kewajibannya tepat pada waktunya. Di lain 
pihak ditinjau dari segi sudut pemegang saham, kinerja yang baik akan selalu menguntungkan karena berpeluang menimbulkan dana-dana yang menganggur yang sebenarnya dapat digunakan untuk berinvestasi dalam proyek- proyek yang menguntungkan perusahaan (Tunggal,2015 : 157).

Keseimbangan antara modal kerja dan kinerja keuangan senantiasa harus diperhatikan. Kinerja keuangan merupakan kemampuan perusahaan dalam memenuhi kewajibannya yang akan segera jatuh tempo dan merupakan kemampuan perusahaan untuk menghasilkan laba. Jadi, jika perusahaan terlalu likuid, artinya banyak modal yang tersimpan dalam bentuk kas, hal ini menimbulkan hilangnya kesempatan untuk memperoleh laba apabila kas tersebut ditanamkan. Namun sebaliknya perusahaan juga tidak boleh menanamkan seluruh uang yang dimiliki dalam usaha, sehingga ketika diperlukan dana cair mengalami kesulitan.

Kas merupakan aktiva yang paling likuid atau merupakan salah satu yang paling tinggi likuiditasnya, berarti semakin besar jumlah kas yang dimiliki oleh suatu perusahaan akan semakin tinggi pula tingkat likuiditasnya. Tetapi suatu perusahaan yang memiliki tingkat likuiditas yang tinggi karena adanya kas dalam jumlah yang besar berarti tingkat perputaran kas tersebut rendah dan mencerminkan adanya over investment dalam kas dan berarti pula bahwa perusahaan kurang efektif dalam mengelola kas. Jumlah kas yang relatif kecil akan diperoleh tingkat perputaran kas yang tinggi dan keuntungan yang diperoleh akan lebih besar, tetapi perusahaan yang hanya mengejar keuntungan (rentabilitas) tanpa memperhatikan likuiditas pada akhirnya perusahan tersebut akan masuk dalam keadaan "illikuid" apabila sewaktu-waktu ada tagihan. Penilaian kinerja keuangan umumnya menggunakan analisa rentabilitas. Rentabilitas suatu perusahaan merupakan perbandingan Rentabilitas dapat dicapai jika tingkat efisiensi dalam perusahaan dapat diwujudkan yaitu dengan menggunakan sumber modal yang ada secara optimal begitupun dengan tingkat likuiditas yang dicapai perusahaan. Tingkat rentabilitas sangat penting bagi PT.Bukit Agung Sehati Palembang karena rentabilitas dapat mencerminkan kemampuan modal suatu perusahaan untuk menghasilkan keuntungan. Semakin tinggi tingkat rentabilitas suatu perusahaan berarti semakin tinggi pula tingkat efisiensi penggunaan modalnya. PT.

Bukit Agung Sehati Palembang merupakan usaha yang bergerak di bidang industri konstruksi, industri pabrikasi, jasa penyewaan, jasa keagenan, investasi, agro industri, Engineering Procurement dan Contruction (EPC) _ perdagangan, pengelolaan kawasan layanan jasa peningkatan kemampuan dibidang konstruksi, teknologi informasi, kepariwisataan,perhotelan,jasa engineering dan perencanaan pengembang untuk menghasilkan barang atau jasa yang bermutu tinggi dan berdaya saing kuat.

Kegiatan usaha yang saat ini dilakukan addalah jasa Konstruksi,Realti (Pengembang), properti dan investasi di bidang infrastruktur dan Energi. PT. Bukit Agung Sehati Palembang sebagai perusahaan yang bergerak di bidang industri konstruksi dan realti (pengembang) membutuhkan metode pendanaan dan pengelolaan dana keuangan yang efektif. Pengelolaan dana yang dimaksud adalah pengelolaan yang wajib mempertimbangkan 
tingkat keamanan, tingkat hasil, dan tingkat rentabilitas yang sesuai dengan kewajiban yang harus dipenuhi. Analisis modal kerja dan likuiditas terhadap kinerja keuangan pada PT. Bukit Agung Sehati Palembang bertujuan untuk mengetahui bagaimana perusahaan tersebut menggunakan modal yang ada serta tingkat likuiditas yang dicapai sehingga berpengaruh terhadap laba yang diperoleh .

Untuk mencapai hal tersebut, perlu adanya perencanaan yang sistematis dalam penggunaan modal. Berikut adalah gambaran tentang modal kerja, dan kinerja keuangan pada PT. Bukit Agung Sehati Palembang Palembang Periode 2015 2019.

Tabel -1

PT. Bukit Agung Sehati Palembang Laporan Keuangan Periode 2015-2019 ( dalam rupiah )

\begin{tabular}{|l|c|c|c|c|c|}
\hline \multicolumn{1}{|c|}{ URAIAN } & \multicolumn{1}{|c|}{$\begin{array}{c}\text { TAHUN } \\
\mathbf{2 0 1 5}\end{array}$} & \multicolumn{1}{|c|}{$\begin{array}{c}\text { TAHUN } \\
\mathbf{2 0 1 6}\end{array}$} & $\begin{array}{c}\text { TAHUN } \\
\mathbf{2 0 1 7}\end{array}$ & $\begin{array}{c}\text { TAHUN } \\
\mathbf{2 0 1 8}\end{array}$ & $\begin{array}{c}\text { TAHUN } \\
\mathbf{2 0 1 9}\end{array}$ \\
\hline $\begin{array}{l}\text { Aktiva } \\
\text { Lancar }\end{array}$ & Rp. 485.189.123,- & Rp. 482.494.348,- & Rp. 477.650.500,- & Rp 495.150.500,- & Rp. 499.750.500 \\
\hline $\begin{array}{l}\text { Hutang } \\
\text { Lancar }\end{array}$ & Rp. 281.434.151,- & Rp.286.629.534,- & Rp. 225.775.000,- & Rp. 226.525.000,- & Rp.210.175.000,- \\
\hline \begin{tabular}{l} 
Modal Kerja \\
\hline
\end{tabular} & Rp. 203.754.972,- & Rp. 195.864.814,- & Rp. 251.875.500,- & Rp. 268.625.500,- & Rp. 289.575.500,- \\
\hline
\end{tabular}

Sumber: Laporan Keuangan PT. Bukit Agung Sehati Palembang

Tabel -2

PT. Bukit Agung Sehati Palembang Perkembangan Laporan Laba-Rugi Tahun 2015-2019

\begin{tabular}{|c|c|c|c|c|c|}
\hline URAIAN & $\begin{array}{c}\text { TAHUN } \\
2015\end{array}$ & $\begin{array}{c}\text { TAHUN } \\
2016\end{array}$ & $\begin{array}{c}\text { TAHUN } \\
2017\end{array}$ & $\begin{array}{c}\text { TAHUN } \\
2018\end{array}$ & $\begin{array}{c}\text { TAHUN } \\
2019\end{array}$ \\
\hline $\begin{array}{l}\text { Penerimaan } \\
\text { (Fungsional dan } \\
\text { Non } \\
\text { Fungsional) }\end{array}$ & Rp. 316.204.350,- & Rp. 320.208.148,- & Rp. 292.022.288,- & Rp. 333.522.288,-- & Rp. 336.022.288,- \\
\hline $\begin{array}{l}\text { Pengeluaran } \\
\text { (Operasional ) }\end{array}$ & Rp. 138.068.465,- & Rp. 135.387.721,- & Rp. 128.283.562,- & Rp. 165.387.721,- & Rp. 158.825.937,- \\
\hline Saldo & Rp. 178.135.885,- & Rp. 184.820.427,- & Rp. 163.738.726,- & Rp. 168.134.567,- & Rp. 177.196.351,- \\
\hline
\end{tabular}

Sumber: Laporan Keuangan PT. Bukit Agung Sehati Palembang

Membaca analisa laporan keuangan PT. Bukit Agung Sehati Palembang sesungguhnya dapat dicermati perkembangan kemampuan keuangan perusahaan pada lima tahun terakhir mengalami fluktuasi yang cukup signifikan dari hal tersebut diatas sehingga dapat diukur ataupun dibandingkan prestasi 
perusahaan dari tahun ke tahun, dan juga dapat mengetahui kelemahan dan kekuatan yang dimiliki oleh perusahaan dan dapat diketahui seberapa besar Tingkat Rentabilitas dengan analisa rasio-rasio ini maka dapat diketahui masalah yang dihadapi perusahaan, sehingga aktivitas perusahaan dapat berjalan secara efektif dan efisien, sehingga dapat meningkatkan penjualan dan rentabilitas perusahaan, dengan kemampuan memenangkan persaingan usaha maupun meningkatnya laba usahanya.

Berdasarkan fenomena di atas, penulis mencoba untuk meneliti sejauh mana modal kerja berpengaruh terhadap rentabilitas. Sebagai bahan perbandingan, penelitian ini merujuk pada penelitian terdahulu yang dilakukan oleh :

- Ati Susanti (2016), dengan judul "Pengaruh Perputaran Modal Kerja Terhadap Rentabilitas pada PT. Jaya Maju bersama". Melalui penelitiannya diperoleh hasil bahwa perputaran modal kerja tidak berpengaruh terhadap rentabilitas.

- $\quad$ Rizal Rizaludin (2017), dengan judul "Pengaruh Modal Kerja Terhadap PT. Adira Finacial Bandung. Melalui penelitiannya diperoleh hasil bahwa penambahan atau pengurangan modal kerja akan mempengaruhi rentabilitas.

\subsection{Rumusan Masalah}

1. Apakah modal kerja berpengaruh terhadap rentabilitas pada PT. Bukit Agung

2. Sehati Palembang selama periode 2015-2019

\subsection{Tujuan Penelitian}

Tujuan diadakannya penelitian ini untuk mengetahui modal kerja mempunyai pengaruh terhadap rentabilitas pada PT. Bukit Agung Sehati Palembang selama periode 2015-2019"

\subsection{Manfaat Penelitian}

Penelitian ini diharapkan dapat memberikan beberapa manfaat yaitu:

1. Hasil penelitian ini diharapkan Sebagai bahan masukan bagi perusahaan dalam mengevaluasi kebijaksanaan yang telah ada dan akan dilaksanakan di masa yang akan datang.

2. Bagi dunia pendidikan, hasil temuan empiris penelitian ini diharapkan dapat memberikan kontribusi terhadap pengembangan literatur Manajemen Keuangan, serta memperkaya referensi bagi pembaca.

3. Penelitian ini diharapkan dapat menjadi bahan perbandingan bagi penelitian- penelitian selanjutnya.

\section{TINJAUAN PUSTAKA}

\subsection{Landasan Teori}

\subsubsection{Pengertian Modal Kerja}

Menurut Kasmir (2018 : 250)

modal kerja merupakan modal yang digunakan untuk melakukan kegiatan operasi perusahaan. Modal kerja juga dapat diartikan sebagai investasi yang ditanamkan dalam aktiva lancar. Apabila perusahaan kekurangan modal kerja untuk memperluas penjualan dan meningkatkan produksinya, maka besar kemungkinan akan kehilangan pendapatan dan keuntungan. Perusahaan yang tidak memiliki modal kerja yang cukup, tidak dapat membayar kewajibannya tepat pada waktunya dan akan menghadapi masalah keuangan. Investasi modal kerja merupakan proses terus-menerus selama 
perusahaan beroperasi.

Menurut Gitman (2015 :105) menjelaskan bahwa modal kerja adalah jumlah harta lancar yang merupakan bagian dari investasi yang bersirkulasi dari satu bentuk ke bentuk yang lain dalam suatu kegiatan bisnis. Weston dan Brigham (2016:98) menjelaskan bahwa manjemen modal kerja adalah investasi perusahaan dalam jangka pendek: kas, surat-surat berharga (efek), piutang,dan persediaan. Masing-masing elemen modal kerja tersebut wajib dikelola agar berada pada keadaan optimal. Menurut Priainah dan Kusuma, (2015 : 114). Elemen-elemen perputaran modal kerja terdiri dari kas, piutang, persediaan yang merupakan elemen dari aktiva lancar.

- Kas (Cash)

Kas menurut (Munawir, 2016) adalah uang tunai yang dapat digunakan untuk membiayai operasi perusahaan.Termasuk dalam pengertian kas adalah check yang diterima dari para langganan dan simpanan perusahaan di Bank dalam bentuk giro atau demand deposit. Kas menggambarkan kemampuan perusahaan untuk membayar kewajiban pada saat jatuh tempo. Jadi kas sangat diperlukan bagi perusahaan untuk menjalankan operasiusahanya.

Tujuan dasar pengelolaan kas adalah untuk meminimumkan saldo kas dengan tetap memperhatikan kemampuan perusahaan untuk memenuhi kewajibannya. Untuk menentukan kas yang optimal sangat tergantung atas trade off antara tingkat bunga dengan biaya transaksi. Jika kondisi yang akan datang diketahui dengan pasti, maka akan sangat mudah menentukan jumlah kas yang optimal. Manajemen modal kerja yang sehat memerlukan pengelolaan jumlah kas yang cukup untuk kepentingan - kepentingan tertentu.

- Piutang (Account Receivable)

Pengertian piutang menurut (Kasmir, 2018) adalah merupakan tagihan perusahaan kepada pihak lainnya yang memiliki jangka waktu tidak lebih dari satu tahun. Menurut (Riyanto, 2016) Piutang merupakan elemen modal kerja yang juga selalu dalam keadaan berputar terusmenerus dalam rantai perputaran modal kerja, yaitu: kas-inventory- piutang-kas. Dalam keadaan yang normal dan dimana penjualan pada umumnya dilakukan dengan kredit, piutang mempunyai tingkat likuiditas yang lebih tinggi daripada inventory, karena perputaran dari piutang ke kas membutuhkan satu langkah saja. Manajemen piutang merupakan hal yang sangat penting bagi perusahaan yang menjual produknya dengan kredit. Manajemen piutang terutama menyangkut masalah pengendalian jumlah piutang, pengendalian pemberian dan pengumpulan piutang, dan evaluasi terhadap politik kredit yang dijalankan oleh perusahaan. Perputaran piutang juga di gunakan untuk mengukur berapa lama penagihan piutang selama satu periode atau berapa kali dana yang ditanam dalam piutang ini berputar dalam satu periode. Semakin tinggi rasio menunjukkan bahwa modal kerja yang ditanamkan dalam piutang semakin rendah dan tentunya kondisi ini bagi perusahaan semakin baik. Sebaliknya jika rasio semakin rendah ada over investment dalam piutang. Hal yang jelas adalah rasio perputaran piutang memberikan pemahaman tentang kualitas piutang dan kesuksesan penagihan piutang (Kasmir, 2018). 
- Persediaan (Inventary)

Persediaan menurut (Kasmir, 2018) merupakan sejumlah barang yang disimpan oleh perusahaan dalam suatu tempat (gudang). Persediaan merupakan cadangan perusahaan untuk proses produksi atau penjualan pada saat dibutuhkan. Elemen utama dari modal kerja ini merupakan aktiva yang selalu dalam keadaan berputar, di mana secara terus menerus mengalami perubahan (Riyanto, 2016: 99). Rasio ini digunakan untuk mengukur berapa kali dana yang ditanam dalam persediaan ini berputar dalam satu periode.Persediaan merupakan salah satu unsur yang penting dalam perusahaan karena jumlah persediaan akan mempengaruhi kelancaran produksi serta efisiensi dan efektifitas perusahaan. Apabila investasi dalam persediaan terlalu besar dibandingkan dengan kebutuhan akan memperbesar beban bunga, memperbesar biaya penyimpanan dan pemeliharaan di gudang, besar kemungkinan kerugian karena kerusakan, turunya kualitas, keusangan sehingga semuanya ini akan memperkecil keuntungan perusahaan. Sebaliknya apabila investasi terlalu kecil dalam inventory akan mempunyai efek yang menekan keuntungan juga, karena kekurangan material, perusahaan tidak dapat bekerja dengan luas produksi yang optimal.

- Premi bayar di muka

Menurut (Munawir ; 2016: 115) adalah biaya-biaya yang belum merupakan kewajiban perusahaan untuk membayarnya pada periode yang bersangkutan, namun sudah dibayarkan terlebih dahulu dan barang/jasa atas pengeluaran tersebut tidak langsung diterima saat itu juga. Karena jumlah yang dibayarkan tersebut belum merupakan beban perusahaan untuk periode yang bersangkutan, maka jumlah yang telah dibayarkan tersebut merupakan uang muka dan termasuk dalam Aktiva Lancar. Segala biaya bayar di muka yang merupakan beban untuk periode-periode berikutnya tidak boleh diakui sebagai beban periodesaat ini, tetapi harus diamortisasi/dibebankan sesuai dengan masa manfaat atas biaya bayar di muka tersebut.

\subsubsection{Pentingnya Moda Kerja yang cukup.}

Modal kerja sebaiknya tersedia dalam jumlah yang cukup agar memungkinkan perusahaan untuk beroperasi secara ekonomis dan tidak mengalami kesulitan keuangan, misalnya dapat menutup kerugian dan mengatasi keadaan krisis atau darurat tanpa membahayakan keadaan keuangan perusahaan. Penyebab timbulnya kelebihan modal kerja adalah sebagai berikut.

a. Pengeluaran saham dan obligasi yang melebihi dari jumlah yang diperlukan.

b. Penjualan aktiva tetap tanpa diikuti penempatan kembali.

c. Pendapatan atau keuntungan yang diperoleh tidak digunakan untuk membayar dividen, membeli aktiva tetap, atau maksud-maksud lainnya.

Kelebihan modal kerja, khususnya dalam bentuk kas dan surat-surat berharga, tidak mengguntungkan karena laba tersebut tidak digunakan secara produktif. Dana yang menganggur, pendapatan yang rendah, investasi pada proyek-proyek yang tidak diinginkan atau fasilitas pabrik dan perlengkapannya yang tidak perlu, 
semuanya merupakan operasi perusahaan yang tidak efisien. Penyebab timbulnya kekurangan modal kerja adalah sebagai berikut:

a. Adanya kerugian usaha. Penyebab adanya kerugian usaha adalah (a) volume penjualan yang tidak efisien relative dibandingkan dengan harga pokok penjualan, (b) tekanan terhadap harga jual akibat ketatnya persaingan tanpa diikuti penurunan harga pokok penjualandan biaya usaha, (c) banyaknya kerugian karena adanya piutang yang tidak kembali, (d) kenaikan biaya tanpa diikuti kenaikan penjualan/penghasilan, (e) biaya naik sementara penjualan menurun. Kerugian usaha tidak selalu akan mengurangi modal kerja karena ada sementara biaya yang tidak bersifat pengeluaran kas (noncash expense) seperti beban penyusutan, depresi, dan amortisasi. Yang jelas kerugian usaha itu mengurangi laba yang di tahan (retained earnings).

b. Adanya kerugian insidensil seperti turunnya harga pasar dan persediaan barang, karena pencurian, kebakaran, dan lain-lain yang tidak ditutup dengan asuransi.

c. Kegagalan mendapatkan tambahan modal kerja pada waktu mengadakan perluasan usaha atau ekspansi seperti perluasan daerah penjualan, penjualan produk baru, penerapan metode produksi baru strategi penjualan baru, dan sebagainya.

d. Menggunakan modal kerja untuk aktiva tidak lancar seperti membali aktiva tetap baru, membeli saham dari perusahaan lain (investasi jangka panjang).

e. Kebijaksanaan pembayaran dividen yang tidak tepat. Karena harapan keuangan terus membaik pimpinan perusahaan masih terus melanjutkan kebijaksanaan pembayaran dividen seperti tahun-tahun sebelumnya.

f. Kenaikan tingkat harga. Karena naiknya harga-harga, perusahaan mengeluarkan jumlah rupiah lebih banyak untuk mempertahankan volume fisik persedian barang dan aktiva tetap serta membelanjai penjualan kredit dalam volume fisik yang sama.

g. Pelunasan utang yang sudah jauh tempo. Manajemen tidak menyisihkan sebagai pendapatan bersih untuk cadangan pelunasan utang jangka panjang.

\subsubsection{Faktor-Faktor Yang Mempengaruhi Jumlah Modal Kerja \\ Menurut Munawir ( ( 2016:117)}

Faktor-faktor yang mempengaruhi jumlah modal kerja adalah sebagai berikut.

a. Sifat umum atau tipe perusahaan.

Modal kerja yang dibutukan perusahaan jasa (public utility) relatif rendah karena investasi dalam persediaan dan piutang pencairannya menjadikan relatif cepat. Untuk beberapa perusahaan jasa tertentu malahan langganan membayar di muka sebelum jasa dinikmati, misalnya jasa transport, kereta api, bus malam, pesawat udara, dan kapal laut. Proporsi modal kerja dari total aktiva, pada perusahaan jasa relatif kecil. Berbeda dengan perusahaan industri, investasi dalam aktiva lancar cukup besar dengan tingkat perputaran persediaan dan piutang yang relatif rendah. Perusahaan industri memerlukan modal kerja yang cukup besar, yakni untuk melakukan investasi dalam bahan baku, barang dalam proses, dan 
barang jadi. Fluktuasi dalam pendapatan bersih dan perusahaan jasa juga relatif kecil bila dibandingkan dengan perusahaan industri dan perusahaan keuangan.

b. Waktu yang diperlukan untuk memproduksi atau mendapatkan barang dan ongkos produksi per unit atau harga beli per unit barang.

Jumlah modal kerja bukan langsung dengan waktu yang dibutuhkan mulai dari bahan baku atau barang jadi dibeli sampai barang-barang dijual kepada langganan. Makin panjang waktu yang diperlukan untuk memproduksi barang atau untuk memperoleh barang makin besar kebutuhan akan modal kerja.

Modal kerja bervariasi tergantung pada volume pembelian dan harga beli per unit dari barang yang di jual. Misalnya suatu perusahaan yang memproduksi lokomotif kereta api, di samping membutuhkan waktu lama dalam proses produksinya juga membutuhkan modal kerja yang besar (bila dibandingkan dengan perusahaan yang memproduksi mebel rumah tangga). Juga perusahaan yang membutuhkan sistem pendinginan (ikan laut) dan perusahaan yang membutuhkan proses pengeringan (tembakau, kayu) akan memerlukan modal kerja yang lebih besar.

\section{c. Syarat pembelian dan penjualan}

Syarat kredit pembelian barang dagangan atau bahan baku akan mempengaruhi besar kecilnya modal kerja. Syarat kredit pembelian yang menguntungkan akan memperkecil kebutuhan uang kas yang harus ditanamkan dalam persediaan, sebaliknya bila pembayaran harus dilakukan segera setelah barang diterima maka kebutuhan uang kas untuk membelanjai volume perdagangan menjadi lebih besar. Di samping itu, modal kerja juaga dipengaruhi oleh syarat kredit penjualan barang. Semakin lunak kredit (jangka kredit lebih panjang) yang diberikan kepada langganan akan semakin besar kebutuhan modal kerja yang harus ditanamkan kepada piutang. Untuk mengurangi kebutuhan modal kerja dan mengurangi risiko kerugian karena adanya piutang yang tidak terbayar, biasanya perusahaan memberikan rangsangan potongan tunai (cash discount).

\section{d. Tingkat perputaran persediaan.}

Semakin sering persediaan diganti (dibeli dan dijual kembali) maka kebutuhan modal kerja yang ditanamkan dalam bentuk persediaan (barang) akan semakin rendah. Untuk mencapai tingkat perputaran persediaan yang tinggi diperlukan perencanaan dan pengawasan persediaan yang efisien. Semakin tinggi tingkat perputaran persediaan akan mengurangi risiko kerugian karena penurunan harga, perubahan pemintaan atau perubahan mode, juga menghemat ongkos penyimpanan dan pemeliharaan (carrying cost) dari persediaan.

\section{e. Tingkat perputaran piutang}

Kebutuhan modal kerja juga tergantung pada periode waktu yang diperlukan untuk mengubah piutang menjadi uang kas. Apa bila piutang terkumpul dalam waktu pendek berarti kebutuhan akan modal kerja menjadi semakin rendah atau kecil. Untuk mencapai tingkat perputaran piutang yang tinggi diperlukan pengawasan piutang yang efektif dan kebijaksanaan yang tepat sehubungan dengan perluasan kredit, syarat kredit penjualan, maksimum kredit bagi langganan, serta penagihan piutang. 


\section{f. Pengaruh konjungtur (business cycle)} Pada periode makmur (prosperity) aktivitas perusahaan meningkat dan perusahaan cenderung membeli barang lebih memanfaatkan harga yang masih rendah. Ini berarti perusahaanmemperbesar tingkat persediaan. Peningkatan jumlah persediaan membutuhkan modal kerja yang lebih banyak. Sebaiknya dalam periode depresi volume perdagangan menurun, perusahaan cepat- cepat berusaha menjual barangnya dan menarik piutangnya. Uang yang di peroleh digunakan untuk membeli surat-surat berharga, melunasi utang, atau untuk menutupi kerugian.

\section{g. Derajat risiko} kemungkinan menurunya harga jual aktiva jangka pendek menurunya nilai riil dibanding dengan harga buku dari suratsurat berharga, persediaan barang, dan piutang akan menurunkan modal kerja. Apabila risiko kerugian ini semakin besar berarti diperlukan tambahan modal kerja untuk membayar bunga atau melunasi utang jangka pendek yang sudah jatuh tempo. Untuk melindungi diri dari hal yang tidak terduga dibutuhkan modal kerja yang relatif besar dalam bentuk kas atau surat-surat berharga.

\section{h. Pengaruh musim} Banyak perusahan yang penjualannya hanya terpusat pada beberapa bulan saja. Perusahaan yang di pengaruhi oleh musim membutuhkan jumlah maksimum modal kerja untuk periode yang relatif pendek. Modal kerja yang ditanamkan dalam bentuk persediaan barang berangsur-angsur meningkat dalam bulan-bulan menjelang puncak penjualan. i. Credit rating dari perusahaan

jumlah modal kerja, dalam bentuk kas termasuk surat-surat berharga, yang dibutuhkan perusahaan untuk membiayai operasionalnya tergantung pada kebijaksanaan penyediaan uang kas. Penyediaan uang kas ini tergantung pada: (a) credit rating dari perusahaan (kemampuan meminjam uang dalam jangka pendek), (b) perputaran persediaan dan piutang,dan (c) kesempatan mendapatkan potongan harga dalam pembelian.

\subsection{Sumber Modal Kerja}

Modal kerja menurut jenisnya dapat dibedakan menjadi dua golongan, yakni sebagai berikut.

a. Bagian modal kerja yang realatif permanen, yaitu jumlah modal kerja minimal yang harus tetap ada dalam perusahaan untuk dapat melaksanakan operasinya atau sejumlah modal kerja yang secara terus-menerus diperlukan untuk kelancaran usaha. Modal kerja permanen ini dapat dibedakan dalam:

1. Modal kerja primer, yaitu jumlah modal kerja minimum yang harus ada pada perusahaan untuk menjamin kontinuitasi usahanya.

2. Modal kerja normal, yaitu jumlah modal kerja yang diperlukan untuk menyelenggarakan luas produksi yang normal.

b. Bagian modal kerja yang bersifat variabel, yaitu modal kerja yang jumlahnya berubah tergantung pada perubahan keadaan. Modal kerja variabel ini dapat dibedakan dalam:

1. Modal kerja musiman, yaitu modal kerja yang jumlahnya berubah-ubah disebabkan dan fluktuasi musim. 
2. Modal kerja siklis, yaitu modal kerja yang jumlahnya berubahubah disebabkan oleh fluktuasi konjungtur.

3. Modal kerja darurat, yaitu modal kerja yang jumlahya berubah-ubah karena adanya keadaan darurat atau mendadak yang tidak dapat diketahui atau diramalkan terlebih dahulu (Bambang Rianto, 2016:52).

Modal kerja dapat berasal dari berbagai sumber, yakni sebagai berikut. a. Pendapatan bersih Modal kerja diperoleh dari hasil penjualan barang dan hasi-hasil lainnya yang meningkatkan uang kas dan piutang. Akan tetapi, sebagian dari modal kerja ini harus di gunakan untuk menutup harga pokok penjualan dan biaya usaha yang telah dikeluarkan untuk memperoleh revenue, yakni berupa biaya penjualan dan biaya administrasi. Jadi, sebenarnya yang merupakan sumber modal kerja adalah pendapatan bersih dan jumlah modal kerja yang diperoleh dari operasi jangka pendek, dan ini bisa ditentukan dengan cara menganalisis laporan perhitungan laba-rugi perusahaan.

Dalam perhitungan laba rugi terdapat dua jenis biaya usaha, yakni (a) pos-pos biaya yang memerlukan penggunaan modal kerja, contohnya pembelian barang dagangan atau bahan baku, pembayaran gaji, upah, dan premi asuransi; (b) pos-pos biaya yang tidak memerlukan pengeluaran kas atau menimbulkan utang yang akhirnya juga tidak memerlukan penggunaan modal kerja, contohnya yaitu beban penyusutan, deplesi, dan amortisasi. Meskipun biayabiaya ini diperhitungkan sebagai biaya usaha dalam menentukan pendapatan bersih, tetapi dalam menghitung jumlah modal kerja yang berasal dari hasil operasi perusahaan, biaya-biaya (noncash) tersebut harus dikeluarkan karena biaya-biaya tersebut tidak menggunakan modal kerja. Lain halnya dengan kasus kerugian karena piutang tidak terbayar. Kerugian piutang tidak terbayar akan mengurangi piutang. Sebaliknya penyusunan harus dikurangkan dari aktiva tetap yang tidak ada pengaruhnya terhadap modal kerja.

a. Keuntungan dari penjualan surat-surat berharga. Surat-surat berharga sebagai salah satu pos aktiva lancar dapat dijual dan dari penjualan ini akan timbul keuntungan. Penjualan suratsurat berharga menunjukan pergeseran bentuk pos aktiva lancar dari pos "suratsurat berharga" menjadi pos "kas". Keuntungan yang diperoleh merupakan sumber penambahan modal kerja. Sebaiknya, jika terjadinya kerugian maka modal kerja akan berkurang.

b. Penjualan aktiva tetap, investasi jangka panjang, dan aktiva tidak lancar lainnya Sumber lain untuk menambah modal kerja adalah hasil penjualan aktiva tetap, investasi jangka panjang, dan aktiva lancar lainnya yang tidak dipergunakan lagi oleh perusahaan. Perubahan aktiva tidak lancar itu menjadi kas yang akan menambah modal kerja sebanyak hasil bersih penjualan aktiva tidak lancar tersebut. Keuntungan atau kerugian dari penjualan investasi jangka panjang dan aktiva tidak lancar lainnya dapat dimasukkan ke dalam pos-pos insidentil (extraordinary item).

c. Penjualan obligasi dan saham serta kontribusi dana dari pemilik Utang hipotik, obligasi, dan saham dapat 
dikeluarkan oleh perusahaan apabila diperlukan sejumlah modal kerja, misalnya untuk ekspansi perusahaan. Pinjaman jangka panjang berbentuk obligasi biasanya tidak begitu disukai karena adanya beban bunga di samping kewajiban mengembalikan pokok pinjamannya.

d. Dana pinjaman dari bank dan pinjaman jangka pendek lainnya. Pinjaman jangka pendek (seperti kredit bank) bagi beberapa perusahaan merupakan sumber penting dari aktiva lancarnya, terutama tambahan modal kerja yang diperlukan untuk membelanjai kebutuhan modal kerja musiman siklis, keadaan darurat, atau kebutuhan jangka pendek lainnya. Karena ketergantunagn akan kredit bank dan kredit jangka pendek lainnya, makanya adanya credit rating yang tingi tingkatnya bagi perusahaan yang bersangkutan adalah sepenuhnya penting.

e. Kredit dari supplier atau trade creditor. Salah satu sumber modal kerja yang penting adalah kredit yang diberikan oleh supplier. Material, barang-barang, supplies, dan jasa-jasa biasa di beli secara kredit atau dengan wesel bayar. Apabila perusahaan kemudian dapat mengusahakan menjual barang dan menarik pembayaran piutang sebelum waktu yang harus di lunasi, perusahaan hanya memerlukan sejumlah kecil modal kerja.

\subsubsection{Penggunaan Modal Kerja}

Penggunaan modal kerja yang mengakibatkan berkurangnya aktiva lancar menurut Munawir (2016:125) adalah

a. Pengeluaran biaya jangka pendek dan pembayaran utang-utang jangka pendek (termasuk utang dividen).

b. Adanya pemakaian prive yang berasal dari keuntungan (pada perusahaan perseorangan dan persekutuan).

c. Kerugian usaha atau kerugian insidentil yang memerlukan pengeluaran kas. d. Pembentukan dana untuk tujuan tertentu seperti dana pensiun pegawai, pembayaran bunga obligasi yang telah jatuh tempo, penempatan kembali aktiva tidak lancar.

e. Pembelian tambahan aktiva tetap, aktiva tidak berwujud, dan investasi jangka panjang.

f. Pembayaran utang jangka panjang dan pembelian kembali saham perusahaan.

Transaksi - transaksi yang mengakibatkan perubahan bentuk aktiva lancar tetapi tidak mengubah jumlah aktiva lancar adalah

a. Pembelian tunai surat-surat berharga.

b. Pembelian tunai barang - barang dagangan.

c. Perubahan suatu bentuk piutang ke bentuk piutang lainnya, misalnya dari piutang dagang menjadi piutang wesel.

Apabila didasarkan pada data neraca, perubahan modal kerja (dalam pengertian modal kerja neto) pada prinsipnya karena pengaruh dari perubahan unsur-unsur rekening tidak lancar (noncurrent accounts). Perubahan unsur-unsur rekening tidak lancar yang mempunyai pengaruh memperbesar modal kerja (neto) adalah: 
a. Berkurangnya aktiva tidak lancar.

b. Bertambahnya utang jangka panjang.

c. Bertambahnya modal saham.

d. Adanya keuntungan dari operasi perusahaan

\subsubsection{Pengertian Rentabilitas}

Rentabilitas merupakan suatu
indikator yang digunakan untuk
menghitung kinerja suatu perusahaan.
Dengan demikian maka tingkat rentabilitas
yang tinggi dapat mengakibatkan
penerimaan yang tinggi pula. Menurut
Bambang Riyanto (2016:114) pengertian
rentabilitas, yaitu: "Rentabilitas adalah
kemampuan suatu perusahaan untuk
menghasilkan laba selama periode
tertentu"Sedangkan pengertian rentabilitas
yang dikemukakan oleh (S. Munawir
2016:99), yaitu: "Menunjukan kemampuan
perusahaan untuk menghasilkan laba
selama periode tertentu",sementara itu
menurut I Made Sudana (2016:103)
rentabilitas yaitu: "Kemampuan

perusahaan untuk menghasilkan laba dengan menggunakan sumber-sumber yang dimiliki perusahaan, seperti aktiva, modal atau penjualan perusahaan.

Menurut Sutrisno (2018:187)

menyatakan bahwa: "Rentabilitas adalah rasio keuntungan untuk mengukur seberapa besar tingkat keuntungan yang dapat diperoleh perusahaan, semakin besar tingkat keuntungan menunjukan semakin baik manajemen dalam mengelola perusahaan" .Rasio rentabilitas bertujuan untuk mengetahui kemampuan bank dalam menghasilkan laba selama periode tertentu, juga bertujuan untuk mengukur tingkat efektifitas manajemen dalam menjalankan operasional perusahaannya. Untuk menilai suatu rentabilitas perusahaan terdapat berbagai macam cara dalam menghitungnya. Ini semua tergantung pada laba dan aktiva atau modal mana yang akan diperbandingkan. Dibawah ini merupakan jenis-jenis dari rentabilitas:

a. Rentabilitas Ekonomi, menurut Bambang Riyanto :

Rentabilitas Ekonomi $=\frac{\text { Laba Usaha }}{\text { Aktiva }} \times 100 \%$ Total

Menurut Martono dan Agus Harjito (2016:61) rentabilitas ekonomi yaitu "kemampuan perusahaan dalam memperoleh laba usaha dengan aktiva yang digunakan untuk memperoleh laba tersebut".

b. Rentabilitas Modal sendiri, menurut Bambang Riyanto:

$$
\text { Rentabilitas Modal Sendiri }=\frac{\text { Laba Usaha }}{\text { sendiri }} \times 100 \% \text { Modal }
$$

Rasio ini mengukur seberapa banyak keuntungan yang menjadi hak pemilik modal sendiri. Karena ini dipergunakan angka laba setelah pajak. Rasio ini menunjukan efisiensi penggunaan modal sendiri suatu perusahaan. 


\subsubsection{Fungsi Rentabilitas}

Seperti rasio-rasio yang lain, rasio rentabilitas juga memiliki fungsi, tidak hanya bagi pemilik usaha atau manajemen saja, tetapi juga bagi pihak di

1. Mengetahui besarnya tingkat laba yang diperoleh perusahaan dalam satu periode

2. Mengetahui posisi laba perusahaan tahun sebelimnya dengan tahun sekarang

3. Mengetahui perkembangan laba dari waktu ke waktu

4. Mengetahui besarnya laba bersih sesudah pajak dengan modal sendiri

5. Mengetahui produktivitas dari seluruh dana perusahaan yang digunakan baik modal pinjaman maupun modal sendiri.

Fungsi rentabilitas adalah untuk mengetahui kemampuan bank dalam menghasilkan profit atau keuntungan melalui operasi bank (Abdullah, 2015:124). Sedangkan beberapa kegunaan dari analisa rentabilitas (ROA) dapat dikemukakan sebagai berikut:

1. Salah satu kegunaannya yang prinsipil ialah sifatnya yang menyeluruh. Apabila perusahaan sudah menjalankan praktik akuntansi yang baik maka manajemen dapat menggunakan teknik analisa rentabilitas (ROA) dalam mengukur efisiensi penggunaan modal kerja, efisiensi produk dan efisiensi bagian penjualan.

2. Analisa rentabilitas (ROA) dapat untuk membandingkan efisiensi penggunaan modal pada perusahaan dengan perusahaan lain sejenis.

3. Analisa rentabilitas (ROA) dapat digunakan untuk mengukur efisiensi tindakan- tindakan yang dilakukan oleh divisi atau bagian, yaitu dengan mengalokasikan semua biaya dan modal ke dalam bagian yang bersangkutan.luar perusahaan, terutama pihak-piha

4. Analisa rentabilitas (ROA) dapat digunakan untuk mengukur rentabilitas dari masing-masing produk yang dihasilkan oleh perusahaan.

5. Rentabilitas (ROA) selain berguna untuk keperluan control, juga berguna untuk keperluan perencanaan.

Di samping kegunaan dari analisa rentabilitas (ROA), terdapat pula kelemahan- kelemahannya yaitu:

1. Salah satu kelemahan yang prinsipil ialah kesukarannya dalam memban dingkan rate of return suatu perusahaan dengan perusahaan lain yang sejenis, mengingat bahwa kadang-kadang praktik akuntansi yang digunakan oleh masing-masing perusahaan tersebut adalah berbeda-beda.

2. Kelemahan lain dari analisa ini adalah terletak pada adanya fluktuasi nilai dari uang (daya belinya).

3. Dengan menggunakan analisa rate of return atau return on investment saja tidak akan dapat digunakan untumengadakan perbandingan antara dua perusahaan atau lebih dengan mendapatkan kesimpulan yang memuaskan.

Rasio - rasio pengukuran Rentabilitas Pada dasarnya, ada beberapa rasio pengukuran rentabilitas, hanya saja rasio yang biasa digunakan untuk mengukur dan membandingkan kinerja profitabilitas atau rentabilitas bank adalah ROE (Return on Equity) dan ROA (Return on Assets). 
Dalam pembahasan mengenai analisis rentabilitas ini dilakukan dengan cara menghitung ROA. Beberapa jenis rasio rentabilitas dapat dikemukakansebagai berikut:

1. Profit Margin

\section{Profit Margin $=\underline{\text { Laba Operasional }} \quad$ x $100 \%$ Total pendapatan}

Angka ini menunjukan berapa besar presentase pendapatan bersih yang diperoleh daro setiap penjualan, semakin besar rasio ini semakin baik, karena dianggap kemampuan perusahaan dalam mendapatkan laba cukup tinggi.

2. Return on Equity

Rasio ini mengukur seberapa banyak keuntungan yang menjadi hak pemilik modal sendiri, rasio ini dinyatakan sebagai berikut :

Return on Equity $=\frac{\text { laba bersih }}{\text { pemegang saham }} \times 100 \%$ Modal

3. Return on Assets

$$
\text { Return on Assets }=\frac{\text { Laba }}{\text { aktiva }} \times 100 \% \text { Total }
$$

Rasio ini menggambarkan perputaran aktiva diukur dari volume pemjualan. Semakin besar rasio ini semakin baik.. hal ini berarti bahwa aktiva dapat lebih cepat berputar dan meraih laba.

4. BOPO

BOPO adalah rasio yang menjelaskan perbandingan antara biaya operasional dan pendapatan operasional yang diterima oleh bank, yang dirumuskan :

\section{BOPO $=\frac{\text { biaya operasional }}{\text { Pendapatan operasional }} \times 100 \%$}

$\begin{array}{ll}\text { 2.1.8 Pengaruh Perputaran Modal } & \text { rasio ini menunjukan efektifnya } \\ \text { Kerja Terhadap Rentabilitaas } & \text { pemanfaatan modal kerja yang tersedia } \\ \text { Perputaran modal kerja } & \text { dalam meningkatkan rentabilitas } \\ \text { merupakan perbandingan antara penjualan } & \text { perusahaan. Ini berarti bahwa semakin } \\ \text { dengan jumlah keseluruhan aktiva lancar } & \text { besar rasio perputaran modal kerja maka } \\ \text { yang dimiliki suatu perusahaan pada suatu } & \text { semakin baik suatu perusahaan dimana } \\ \text { periode akuntansi tertentu. Semakin besar } & \text { persentase modal kerja yang ada mampu }\end{array}$


menghasilkan jumlah penjualan tertentu. Tingkat perputaran modal kerja mengukur berapa kali aktia lancar mampu berputar untuk menghasilkan penjualan. Semakin cepat modal kerja berputar semakin banyak penjualan yang berhasil tercipta. Dengan peningkatan penjualan dapat dipastikan terjadi peningkatan profitabilitas. Working capital turnover ratio digunakan untuk mengukur perputaran modal kerja yaitu rasio penjualan terhadap aktiva lancar. Penelitian yang dilakukan oleh Raheman dan Nasr (2007) yang menyatakan bahwa working capital turnover ratio berpengaruh positif signifikan terhadap tingkat profitabilitas perusahaan di Pakistan.

\subsection{Penelitian Terdahulu}

Tabel -3

Ringkasan Hasil Penelitian Terdahulu

\begin{tabular}{|c|c|c|c|c|}
\hline No. & Peneliti & Judul & Metode Penelitian & $\begin{array}{c}\text { Hasil } \\
\text { Peneltian }\end{array}$ \\
\hline 1. & $\begin{array}{l}\text { Dewa Putu } \\
\text { Kumara, I } \\
\text { Dewa Gede } \\
\text { Dharma } \\
\text { Saputra } \\
(2014)\end{array}$ & $\begin{array}{l}\text { Pengaruh Efisiensi Modal } \\
\text { Kerja Terhadap Renta } \\
\text { bilitas Pada } \\
\text { Citra Tani Indmira } \\
\text { yogyakarta }\end{array}$ & $\begin{array}{l}\text { Menggunakan } \\
\text { analisis regresi } \\
\text { linier sederhana }\end{array}$ & $\begin{array}{l}\text { Hasil dari penelitian } \\
\text { tersebut adalah perputaran } \\
\text { modal kerja berpengaruh } \\
\text { negatif signifikan terhadap } \\
\text { rentabili tas, yang berarti } \\
\text { bahwa semakin tinggi } \\
\text { perputaran modal kerja } \\
\text { maka akan menurunkan } \\
\text { tingkat rentablitas } \\
\text { PT.Indmira Citra Tani } \\
\text { Nusantara yogyakarta }\end{array}$ \\
\hline 2. & $\begin{array}{l}\text { Ni Putu Putri } \\
\text { Wirasari dkk } \\
(2016)\end{array}$ & $\begin{array}{l}\text { Pengaruh Perputaran } \\
\text { Modal Kerja, terhadap } \\
\text { Rentabilitas pada PT.PLN } \\
\text { (Persero) Semarang" }\end{array}$ & $\begin{array}{l}\text { Regresi Linier } \\
\text { Sederhana }\end{array}$ & $\begin{array}{l}\text { Hasil dari penelitian } \\
\text { tersebut adalah } \\
\text { menunjukkan bahwa } \\
\text { perputaran modal secara } \\
\text { parsial berpengaruh positif } \\
\text { dan signifikan terhadap } \\
\text { Renta bilitas pada PT. PLN } \\
\text { (Persero) Semarang" }\end{array}$ \\
\hline 3. & $\begin{array}{l}\text { Ni Made } \\
\text { Yandyawati } \\
\text { Dkk (2015) }\end{array}$ & $\begin{array}{l}\text { Pengaruh Efektifitas } \\
\text { Penggunaan Modal Kerja } \\
\text { pada Rentabilitas Pada } \\
\text { PT. Surya Mas Duta } \\
\text { Semarang }\end{array}$ & $\begin{array}{l}\text { Menggunakan } \\
\text { analisis Regresi } \\
\text { sedehana. }\end{array}$ & $\begin{array}{l}\text { Hasil dari penelitian } \\
\text { tersebut adalah } \\
\text { menunjukkan bahwa } \\
\text { Pengaruh Efektifitas } \\
\text { Penggunaan Modal Kerja } \\
\text { pada Rentabilitas Pada } \\
\text { PT. Surya Mas Duta } \\
\text { Semarang berpengaruh } \\
\text { secara signifikan }\end{array}$ \\
\hline
\end{tabular}




\begin{tabular}{|c|c|c|c|c|}
\hline 4. & $\begin{array}{l}\text { Endar } \\
\text { Yunitasari } \\
(2016)\end{array}$ & $\begin{array}{l}\text { Pengaruh efisiensi modal } \\
\text { kerja, terhadap rentabilitas } \\
\text { pada PT.Telekomunikasi }\end{array}$ & $\begin{array}{l}\text { Analisi Regresi } \\
\text { Linier Sederhana }\end{array}$ & $\begin{array}{l}\text { Hasil dari penelitian } \\
\text { tersebut adalah } \\
\text { menunjukkan bahwa } \\
\text { Pengaruh Efesiensi } \\
\text { Penggunaan Modal Kerja } \\
\text { terhadap Rentabilitas Pada } \\
\text { PT.Telekomunikasi } \\
\text { berpengaruh secara } \\
\text { signifikan }\end{array}$ \\
\hline
\end{tabular}

Sumber data: diolah peneliti

\subsection{Kerangka Fikir}

Kerangka berpikir menggabarkan pengaruh antara variabel bebas terhadap variabel terikat yaitu pengaruh Modal kerja terhadap Kinerja Keuangan pada PT. Bukit Agung Sehati Palembang.

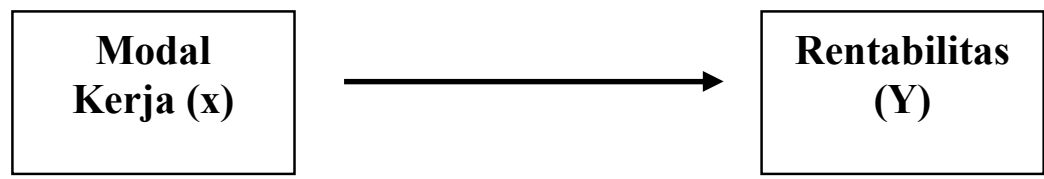

Gambar 1

Kerangka Pikir Penelitian

\subsection{Hipotesis}

Dalam penelitian ini diajukan sebuah hipotesis sebagai jawaban sementara terhadap permasalahan yang telah dikemukakan. Adapun hipotesis yang diajukan dalam penelitian ini adalah : "Ada modal kerja terhadap rasio rentabilitas".

\section{METODOLOGI PENELITIAN}

\subsection{Obyek Penelitian}

Penelitian ini dilakukan di PT. Bukit Agung Sehati Palembang yang beralamat di Jalan Padat Karya Rt.4 No.18 Kelurahan Talang Buluh Kecamatan Talang Kelapa Kabupaten Banyuasin.

\subsection{Ruang Lingkup Penelitian}

Ruang lingkup penelitian adalah Modal Kerja terhadap kinerja keuangan di PT. Bukit Agung Sehati Palembang, laporan keuangan yaitu Neraca dan Rugi- laba

\subsection{Desain Penelitian}

Desain penelitian merupakan pedoman yang digunakan dalam proses penelitian, oleh karena itu perlu disusun desain penelitian yang sistematis untuk menentukan langkah-langkah yang akan dilakukan dalam penelitian. Objek dari penelitian ini adalah berkaitan atau pengaruh Modal kerja terhadap kinerja keuangan pada PT. Bukit Agung Sehati Palembang tahun 2015-2019. Penulis menggunakan 
jenis penelitian ini dengan alasan bahwa setiap perusahaan mempunyai suatu keadaa atau kondisi yang berbeda-beda, hal ini disebabkan adanya nperbedaan besar kecilnya perusahaan dan jenis perusahaan.

Pengertian studi kasus dijelaskan oleh Djahidin (2015:66) sebagai berikut : "Studi kasus adalah peneltian tentang status obyek penelitian yang berkenan dengan fase spesifik atau khas dari keseluruhan personalitas. Subyek penelitian pendapat saja individu, kelompok, lembaga ataupun masyarakat"

\subsection{Jenis dan Sumber Data}

\subsubsection{Data Primer}

Menurut Sugiyono (2016 : 308)

Data primer adalah data yang langsung memberikan data kepada pengumpul data. Dalam menyusun penelitian ini, data primer yang digunakan adalah kuesioner langsung ke PT Bukit Agung Sehati Palembang. Wawancara dilakukan kepada Pemilik PT Bukit Agung sehati Palembang sedangkan observasinya langsung kepada pekerjaan yang akan dituju.

\subsubsection{Data Sekunder}

Menurut Sugiyono (2016 : 309) Data Sekunder adalah data yang di dapat oleh penulis secara tidak langsung seperti litelatur dan penelitian mengenai objek penelitian tersebut.

\subsection{Definisi Operasional}

\begin{tabular}{|c|c|c|c|}
\hline Variabel & Definisi & Indikator & $\begin{array}{c}\text { Skala } \\
\text { Pengukuran }\end{array}$ \\
\hline Modal Kerja & $\begin{array}{l}\text { Setiap perusahaan yang melakukan } \\
\text { kegiatannya selalu membutuhkan } \\
\text { dana.Kebutuhan dana tersebut diguna } \\
\text { kan untuk membiayai kebutuhan } \\
\text { investasi maupun untuk memenuhi } \\
\text { kebutuhan operasional sehari-hari. Dana } \\
\text { yang diperlukan oleh perusa haan untuk } \\
\text { memenuhi kebutuhan operasional } \\
\text { perusahaan sehari-hari, seperti pembelian } \\
\text { bahan baku, pemba yaran upah buruh, } \\
\text { membayar hutang, dan pembayaran } \\
\text { lainnya disebut modal kerja. Sutrisno } \\
\text { (2017): }\end{array}$ & $\begin{array}{l}\text { Rasio-rasio keuangan } \\
\begin{array}{l}\text { - } \quad \text { Kas (uang tunai) } \\
-\quad \text { Piutang(penagihan) } \\
-\quad \text { Persediaan } \\
\text { (barang-barang } \\
\text { yang disimpan) } \\
\text { - Premi yang dibayar } \\
\text { dimuka (biaya yang } \\
\text { dibayar dimuka) }\end{array}\end{array}$ & Rasio \\
\hline Rentabilitas & $\begin{array}{l}\text { Rentabilitas adalah rasio keuntungan } \\
\text { untuk mengukur seberapa besar tingkat } \\
\text { keuntungan yang dapat diperoleh } \\
\text { perusahaan, semakin besar tingkat } \\
\text { keuntungan menunjukan semakin baik } \\
\text { manajemen dalam mengelola } \\
\text { perusahaan" Sutrisno (2018:187) }\end{array}$ & $\begin{array}{ll}\text { - } & \text { Return On Assets } \\
& \text { (ROA). } \\
\text { - } & \text { Return On Equity } \\
& \text { (ROE) } \\
\text { - } & \text { Biaya Pendapatan Ope } \\
& \text { rasional (BOPO) } \\
\text { - } & \text { NPM }\end{array}$ & Rasio \\
\hline
\end{tabular}

\subsection{Teknik Analisis Data} Dalam penyusunan proposal skripsi akhir ini, penulis menggunakan tehnik analisis kualitatif, yaitu tehnik 
analisis yang di pakai guna menganalisis Pengaruh penggunaan modal kerja terhadap rasio profitabilitas secara kualitatif (perbandingan praktek lapangan dengan teori yang di dapat penulis dibangku kuliah).

\subsubsection{Metode Analisis Regresi Linier Sederhana}

Analisis Regresi linear sederhana yaitu analisis yang digunakan untuk meng hitung pengaruh variabel independen (X) terhadap variabel dependen (Y) apabila terjadi perubahan pada satu satuan dari variabel independen (X).

Rumus yang digunakan adalah:

$$
\begin{aligned}
& \mathbf{Y}=\mathbf{a}+\mathbf{b x} \\
& \mathbf{a}=\frac{\Sigma \mathbf{y}_{1}-\frac{\mathbf{b} \underline{\Sigma}_{\mathbf{x}}}{\mathbf{n}}}{\mathbf{n}}=\frac{\mathbf{n} \Sigma \mathbf{x}_{1} \underline{\mathbf{y}}_{1}-\mathbf{n} \Sigma \mathbf{x}_{1 \Sigma} \underline{\mathbf{y}}_{1}}{\mathbf{n} \Sigma \mathbf{x}_{1}{ }^{2}-\left(\Sigma \mathbf{x}_{1}\right)^{2}}
\end{aligned}
$$

Dimana :

$\mathrm{Y}=$ Rasio Profitabilitas

$\mathrm{a}=$ Koefisien regresi konstan

$\mathrm{X}=$ Modal kerja

$\mathrm{b}=$ Koefisien regresi independen pertama

3.6.2 Koefisien determinasi (R2) digunakan untuk melihat besarnya pengaruh variable $\mathrm{X}$ terhadap $\mathrm{Y}$.

Koefesien diterminasi dengan simbol $r^{2}$ merupakan proporsi variabilitas dalam suatu data yang dihitung didasarkan pada model statistik. Definisi berikutnya menyebutkan bahwa $r^{2}$ merupakan rasio variabilitas nilai-nilai yang dibuat model dengan variabilitas nilai data asli. Secara umum $r^{2}$ digunakan sebagai informasi mengenai kecocokan suatu model. Dalam regresi $r^{2}$ ini dijadikan sebagai pengukuran seberapa baik garis regresi mendekati nilai data asli yang dibuat model. Jika $\mathrm{r}^{2}$ sama dengan 1, maka angka tersebut menunjukkan garis regresi cocok dengan data secara sempurna. Interpretasi lain ialah bahwa $r^{2}$ diartikan sebagai proporsi variasi tanggapan yang diterangkan oleh regresor (variabel bebas / X) dalam model. Dengan demikian, jika $\mathrm{r}^{2}=1$ akan mempunyai arti bahwa model yang sesuai menerangkan semua variabilitas dalam variabel Y. jika $r^{2}=0$ akan mempunyai arti bahwa tidak ada hubungan antara regresor $(\mathrm{X})$ dengan variabel $\mathrm{Y}$. Dalam kasus misalnya jika $r^{2}=0,8$ mempunyai arti bahwa sebesar $80 \%$ variasi dari variabel Y (variabel tergantung / response) dapat diterangkan dengan variabel $\mathrm{X}$ (variabel bebas / explanatory); sedang sisanya 0,2 dipengaruhi oleh variabel-variabel yang tidak diketahui atau variabilitas yang inheren. (Rumus untuk menghitung koefesien determinasi (KD) adalah $\mathrm{KD}=$ $\left.r^{2} x \quad 100 \%\right)$ Variabilitas mempunyai makna penyebaran / distribusi seperangkat nilainilai tertentu. Dengan menggunakan bahasa umum, pengaruh variabel $\mathrm{X}$ terhadap $\mathrm{Y}$ adalah sebesar $80 \%$; sedang sisanya $20 \%$ dipengaruhi oleh faktor lain.

\section{HASIL DAN PEMBAHASAN \\ 4.1 Gambaran Umum Perusahaan 4.1.1 Sejarah Perusahaan}

PT. Bukit Agung Sehati Palembang merupakan usaha yang bergerak di bidang industri konstruksi, industri pabrikasi, jasa penyewaan, jasa keagenan, investasi, agro industri, Engineering 
Procurement dan Contruction (EPC) perdagangan, pengelolaan kawasan layanan jasa peningkatan kemampuan dibidang konstruksi, teknologi informasi, kepariwisataan, perhotelan, jasa engineering dan perencanaan pengembang untuk menghasilkan barang atau jasa yang bermutu tinggi dan berdaya saing kuat..Kegiatan usaha yang saat ini dilakukan addalah jasa Konstruksi,Realti (Pengembang), properti dan investasi di bidang infrastruktur dan Energi. PT. Bukit Agung Sehati Palembang sebagai perusahaan yang bergerak di bidang industri konstruksi dan realti (pengembang) membutuhkan metode pendanaan dan pengelolaan dana keuangan yang efektif. Pengelolaan dana yang dimaksud adalah pengelolaan yang wajib mempertimbangkan tingkat keamanan, tingkat hasil, dan tingkat rentabilitas yang sesuai dengan kewajiban yang harus dipenuhi. Analisis modal kerja dan likuiditas terhadap kinerja keuangan pada PT. Bukit Agung Sehati Palembang bertujuan untuk mengetahui bagaimana perusahaan tersebut menggunakan modal yang ada serta tingkat likuiditas yang dicapai sehingga berpengaruh terhadap laba yang diperoleh .

\subsubsection{Visi dan Misi Perusahaan}

Adapun maksud dan tujuan pendirian perusahaan ini, untuk memajukan perindustrian dan menunjang kepentingan masyarakat umum dalam menjalankan perekonomiannya,maka kami berkomitmen membantu Perusahaan dalam menyalurkan produk-produknya dengan efektif dan efesien. Visi Perusahaan berkomitmen memberikan pelayanan terbaik untuk setiap pelanggan. Misi menjadikan kinerja, ketepatan waktu, penilaian terbaik bagi pelanggan kami sebagai wujud penghargaan dari kami dan menciptakan, memelihara keharmonisan hubungan dengan pelanggan disekitar kegiatan usaha untuk membangun kemitraan yang saling menguntungkan.

\subsubsection{Struktur Organisasi dan Uraian Tugas}

Fungsi organisasi dalam suatu perusahaan meliputi penentuan kegiatan yang diperlukan untuk mencapai tujuan perusahaan, pengelompokkan aktifitas dan penentuan tanggung jawab serta penyerahan wewenang untuk melaksanakan dan mempertanggung jawabkan aktivitasaktivitas tersebut.

\subsubsection{Struktur Organisasi PT. Bukit Agung Sehati Palembang}

Struktur organisasi suatu perusahaan memegang peranan penting dalam menentukan pertanggung jawaban tingkatanmanajemen. 
Gambar -2

STRUKTUR ORGANISASI

PT. Bukit Agung Sehati Palembang

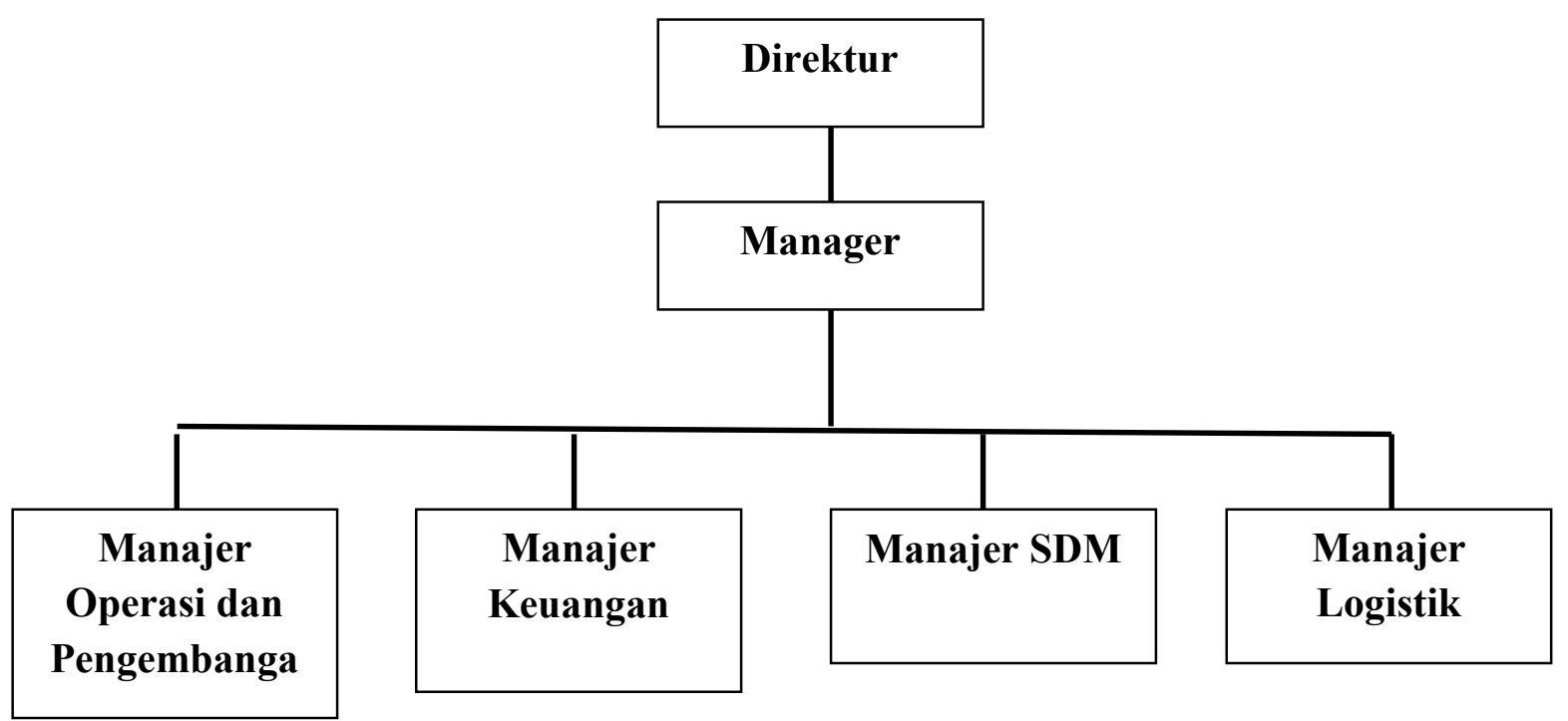

Sumber : PT.Bukit Agung Sehati Palembang 


\subsubsection{Pembagian Tugas}

Dari struktur organisasi rang
dimiliki PT. Bukit Agung Sehati
Palembang, maka dapat dikatakan bahwa
struktur organisasi tersebut masih sangat
sederhana. Dimana struktur organisasinya
adalah bentuk garis (line organization),
yang menggambarkan hubungan antara
atasan dan bawahan yang bersifat
langsung melalui suatu garis wewenang.
Adapun pembagian tugas dan tanggung
jawab dari masing-masing bagian dalam
lingkungan PT. Bukit Agung Sehati
Palembang adalah sebagai berikut:

\section{- Direktur}

- Merencanakan, mengorganisaasikan, menyelenggarakan dan mengendalikan rencana jangka panjang dan rencana kerja dan anggaran perusahaan.

- Merencanakan, mengorganisasikan, menyelenggarakan dan mengendalikan kegiatan opaerasional perusahaan

- Merencanakan, meangorganisasikan, menyelenggarkan, mengendalikan dan mengamankan kaekayaan Perusahaan.

- Merencanakan, mengorganisasikan, menyelenggarakan dan mengembang kan serta mengendalikan strategi bisnis perusahaan.

- Merencanakan, Mengorganisasikan, menyelenggarakan dan mengembang kan serta mengendalikan kegiatan evaluasi berkala terhadap kinerja para Manager perusahaan.

- Merencanakan, mengorganisaasikan, menyelenggarakan dan mengendaliakn strategi pemecahan masalah teknis operasional perusahaan.

- Mewakili kepentingan perusahaan, baik kedalam maupun keluar berdasar kan kewenangan yang dilimpahkan direksi. a. Merencanakan, mengkoordinasikan, menyelenggarakan dan mengawasi kegiatan promosi perusahaan.

b. Merencanakan, Mengkoordinasikan, menyelenggarakan serta meangawasi penyusunan dan penyajian lapoaran statistik perusahaan.

- Manajer Keuangan

Manajer Keuangan mempunyai tugas :

a. Merencanakan, mengkoordinasikan , menyelenggarakan dan mengendalikan rencana kerja dan anggaran Bagian keuangan.

b. Merencanakan,mengkoordinasikansian, menyelenggarakan dan mengawasi penyusunan rencana jangka panjang dan rencana kerja dan anggaran perusahaan.

c. Merencanakan, mengkoordinasikan, menyelenggarakan dan mengawasi kegiatan tresuri dan perpajakan perusahaan.

d. Merencanakan,mengkoordinasikan, menyelenggarakan dan mengawasi verikasi dokumen keuangan, pembukuan serta menyajikan laporan keuangan perusahaan.

e. Merencanakan, Mengkoordinasikan, menyelenggarakan serta meangawasi kegiatan pengelolaan keuangan perusahaan dan pelaporannya.

- Manajer SDM Manajer SDM mempunyai tugas :

a. Merencanakan,mengkoordinasikan, menyelenggarakan dan mengendalikan rencana kerja dan anggaran Bagian SDM

b. Merencanakan, mengkoordinasikan, menyelenggarakan dan mengawasi administrasi dan pengembangan SDM

c. Merencanakan, Mengkoordinasikan, menyelenggarakan serta mengawasi 
kesejahteraan SDM

- Manajer Logistik

Manajer Logistik mempunyai tugas

a. Merencanakan, mengkoordinasikan , menyelenggarakan dan mengendalikan penyusunan rencana kerja dan anggaran Bagian Logistik.

b. Merencanakan, mengkoordinasikansian, menyelenggarakan dan mengawasi kebutuhan perlengkapan rumah tangga serta bangunan.

c. Merencanakan, mengkoordinasikan, menyelenggarakan dan mengawasi tata usaha, perlengkapan, rumah tangga dan bangunan perusahaan.

d. Merencanakan, mengkoordinasikan, menyelenggarakan dan mengawasi kegiatan teknik bangunan.

e. Merencanakan, Mengkoordinasikan, menyelenggarakan serta meangawasi kegiatan tata usaha pembanguan.

\subsection{Analisa Rasio Keuangan}

Untuk menganalisa atau menentukan rasio keuangan suatu perusahaan ada beberapa macam rasio, namun dalam penelitian ini peneliti hanya menggunakan dua rasio yaitu rasio likuiditas dan rasio profitabilitas seperti yang telah penulis kemukakan sebelumnya.

\subsubsection{Rasio Likuiditas}

Rasio likuiditas adalah tingkat kemampuan perusahaan untuk memenuhi kewajibannya yang harus segera dipenuhi dan likuiditas menunjukan tingkat kemampuan perusahaan untuk membayar hutang - hutang jangka pendek yang dimilikinya.

\subsubsection{Rasio Rentabilitas}

Rentabilitas adalah kemampuan perusahaan memperoleh laba melalui operasional usahanya dengan menggunakan dana aset yang dimiliki oleh perusahaan. Menurut sartono (2012) profitabilitas adalah kemampuan perusahaan memperoleh laba dalam hubungannya dengan penjualan, total aktiva maupun modal sendiri.

Pengertian lain juga menyebutkan bahwa rentabilitas menunjukan kemampuan perusahaan untuk menghasilkan keuntungan dan mengukur tingkat efisiensi operasional dan efisiensi dalam menggunakan harta yang dimilikinya (Mas'ud,2015). Laba merupakan salah satu toalk ukur keberhasilan kinerja perusahaan. Selain itu, laba juga sering dijadikan salah satu indikator yang dilihat para investor sebelum mereka menginvestasikan dana mereka karena laba menggambarkan kemampuan perusahaan untuk memenuhin kewajiban mereka kepada pemegang ssaham. Bagi perusahaan, laba menjadi hal yang penting karena laba menjadi salah satu faktor yang mempengaruhi struktur modal perusahaan guna melaksnakan kegiatan operasional tersebut. Dalam menilai profitabilitas dapat dilihat dati ntiga sudut pandang, yaitu return on equity (ROE), return on asset (ROA) dan return on equity (ROE) sebagai proksi dari profitabilitas yang diukur dengan membandingkan laba setelah pajak dengan penggunaan dari modal sendiri. Rasio yang digunakan pada analisa ratio rentabilitas, yaitu :

\subsubsection{Profit Margin}

$$
=\frac{\text { Lab Operasional }}{\text { Pendapatan }} \times 100 \% \text { Total }
$$

Rasio ini menunjukkan laba bersih yang dihasilkan dari setiap rupiah pendapatan. 


$$
\begin{aligned}
\text { Tahun } 2015 & =\frac{178.135 .885}{150.252 .375} \times 100 \% \\
& =118,55 \%
\end{aligned}
$$

Profit Margin Rasio Rentabilitas atau kemampuan untuk menghasilkan laba sebesar $118,55 \%$. Ini bearti setiap rupiah penjualan menghasilkan laba bruto Rp.1,185.

$$
\begin{aligned}
\text { Tahun } 2016 & =\frac{184.820 .427}{150.648 .216} \times 100 \% \\
& =122,68 \%
\end{aligned}
$$

Profit Margin Rasio Rentabilitas atau kemampuan untuk menghasilkan laba bersih sebesar $122,68 \%$. Ini bearti setiap rupiah penjualan menghasilkan laba bersih Rp. 1,226

$$
\begin{aligned}
\text { Tahun } 2017 & =\frac{163.738 .726}{152.252 .375} \times 100 \% \\
& =107,54 \%
\end{aligned}
$$

Profit Margin Rasio Rentabilitas atau kemampuan untuk menghasilkan laba bruto sebesar $107,54 \%$. Ini bearti setiap rupiah penjualan menghasilkan laba bruto Rp.1,075.

$$
\begin{aligned}
\text { Tahun } 2018 & =\frac{168.134 .567}{155.648 .216} \times 100 \% \\
& =108,02, \%
\end{aligned}
$$

Profit Margin Rasio Rentabilitas atau kemampuan untuk menghasilkan laba bruto sebesar 108,02 \% . Ini bearti setiap rupiah penjualan menghasilkan laba bruto $\mathrm{Rp} 1,080$.

$$
\begin{aligned}
\text { Tahun } 2019 & =\frac{177.196 .351}{164.500 .000} \times 100 \% \\
& =107,72 \%
\end{aligned}
$$

Profit Margin Rasio Rentabilitas atau kemampuan untuk menghasilkan laba bruto sebesar 107,7 \% . Ini bearti setiap rupiah penjualan menghasilkan laba bruto Rp. 1,077

\section{Tabel -4}

\section{Profit Margin Rasio Rentabilitas}

\section{PT. Bukit Agung Sehati Palembang}

\begin{tabular}{|c|c|c|c|c|}
\hline Tahun & $\begin{array}{c}\text { Laba } \\
\text { Operasional }\end{array}$ & $\begin{array}{c}\text { Total } \\
\text { Pendapatan }\end{array}$ & $\begin{array}{c}\text { P.M } \\
\text { Rentabilitas }\end{array}$ & Hasil Penelitian \\
\hline 2015 & 178.135 .885 & 150.252 .375 & 118,55 & Tahun Dasar \\
\hline 2016 & 184.820 .427 & 150.648 .216 & 122,68 & Menurun \\
\hline 2017 & 163.738 .726 & 152.252 .375 & 107,54 & Menurun \\
\hline 2018 & 168.134 .567 & 155.648 .216 & 108,02 & Meningkat \\
\hline 2019 & 177.196 .351 & 164.500 .000 & 107,72 & Menurun \\
\hline
\end{tabular}

Sumber : Diolah dari Laporan Laba Rugi PT. Bukit Agung Sehati Palembang

Profit Margin Rasio Rentabilitas untuk mengukur laba bruto per Rp.1,00 penjualan pada Tahun 2015 adalah
$118,55 \%$, pada tahun 2016 mengalami kemunduran sedikit sebesar $4,13 \%$ yaitu mencapai 122,68\%, dan pada tahun 2017 
mengalami penurunan kembali sebesar $15,14 \%$ yaitu sebesar $107,54 \%$, Pada tahun 2018 mengalami peningkatan sebesar $1 \%$ yaitu mencapai $108,2 \%$ dan pada tahun 2019 juga mengalami kemunduran sebesar $1 \%$ yaitu mencapai $107,72 \%$. hal ini menunjukan Rentabilitaas pada PT.Bukit Agung Sehati Palembang adalah kurang baik karena kelima mengalami penurunan ini diakibatkan oleh Harga Pokok Penjualan yang tinggi di tahun ini yang menyababkan profit Marginnya menurun.

\subsubsection{Net Profit Margin}

$$
=\frac{\text { Lab Bersih }}{\text { Penjualan }} \times 100 \%
$$

Rasio ini menunjukkan seakin tinggi laba yang dihasilkan dari setiap rupiah pendapatan.

$$
\begin{aligned}
\text { Tahun } 2015 & =\frac{150.252 .375}{828.635 .110} \times 100 \% \\
& =18,13 \%
\end{aligned}
$$

Net profit margin atau keuntungan neto per Rp.1,00 penjualan sebesar 18,13 \%. Ini berarti setiap Rp.1,00 penjualan menghasilkan keuntungan neto sebesar Rp.

0,18 .

Tahun $2016=\frac{150.648 .216}{928.635 .110} \times 100 \%$

$$
=16,22 \%
$$

Net profit margin atau keuntungan neto per Rp.1,00 penjualan sebesar $16,220,16$.

$$
\text { Tahun } \begin{aligned}
2017 & =\frac{152.252 .375}{828.635 .110} \times 100 \% \\
& =18,37 \%
\end{aligned}
$$

Net profit margin atau keuntungan neto per Rp.1,00 penjualan sebesar 18,370,18.

$$
\text { Tahun } \begin{aligned}
2018 & =\frac{155.648 .216}{928.635 .110} \times 100 \% \\
& =16,76 \%
\end{aligned}
$$

Net profit margin atau keuntungan neto per Rp.1,00 penjualan sebesar 16,76 \%. Ini berarti setiap Rp.1,00 penjualan menghasilkan keuntungan neto sebesar Rp.0,17.

$$
\text { Tahun } \begin{aligned}
2019 & =\frac{164.500 .000}{949.635 .110} \times 100 \% \\
& =17,32 \%
\end{aligned}
$$

Net profit margin atau keuntungan neto per Rp.1,00 penjualan sebesar 17,32\%. Ini berarti setiap Rp.1,00 penjualan menghasilkan keuntungan neto sebesar Rp.0,17.

Tabel -5

Net Profit Margin

PT. Bukit Agung Sehati Palembang

\begin{tabular}{|c|c|c|c|c|c|}
\hline Tahun & Laba Bersih & Penjualan & $\begin{array}{c}\text { Net Profit } \\
\text { Margin }\end{array}$ & $\begin{array}{c}\text { Standar } \\
\text { Rasio }\end{array}$ & Hasil Penelitian \\
\hline 2015 & 150.252 .375 & 828.635 .110 & $18,13 \%$ & $20 \%$ & dibawah standar \\
\hline 2016 & 150.648 .216 & 928.635 .110 & $16,22 \%$ & $20 \%$ & dibawah standar \\
\hline
\end{tabular}




\begin{tabular}{|c|c|c|c|c|c|}
\hline 2017 & 152.252 .375 & 828.635 .110 & $18,37 \%$ & $20 \%$ & dibawah standar \\
\hline 2018 & 155.648 .216 & 928.635 .110 & $16,76 \%$ & $20 \%$ & dibawah standar \\
\hline 2019 & 164.500 .000 & 949.635 .110 & $17,32 \%$ & $20 \%$ & dibawah standar \\
\hline
\end{tabular}

Net Profit Margin untuk mengukur keuntungan neto per rupiah penjualan pada tahun 2015 yaitu mencapai $26,89 \%$,dan pada tahun 2016 mengalami penurunan $1,61 \%$ yaitu mencapai 26,48 \% dan pada tahun 2017 mengalami kenaikan sebanyak 0,56\% yaitu mencapai 24,76\%, begitu juga tahun 2018 dan 2019 mengalami penurunan juga dari kelima tahun diatas dapat dilihat bahwa pada PT. Bukit Agung Sehati Palembang Net Profit Marginnya sudah diatas standar industrial yang baik yaitu $20 \%$ dari kelima tahun tersebut.

\subsubsection{Net earning power ratio ( Rate of return on Investment ROI)}

\section{Rumus :}

$$
\begin{aligned}
& \text { Net earning power ratio }=\text { netto sesudah pajak } \quad \times 100 \% \\
& \text { Jumlah Aktiva } \\
& \text { Tahun } 2015=\frac{150.252 .375}{485.189 .123} \times 100 \% \\
& =\quad 30,96 \%
\end{aligned}
$$

Net earning power ratio merupakan kemampuan untuk menghasilkan keuntungan neto sebesar 30,96\%. Ini berarti kemampuan dari modal yang diinvestasikan dalam keseluruhan aktiva untuk menghasilkan keuntungan neto sebesar

Rp.0,31.

$$
\begin{aligned}
\text { Tahun } 2016 \quad & =\frac{150.648 .216}{482.494 .348} \times 100 \% \\
& =31,22 \%
\end{aligned}
$$

Net earning power ratio merupakan kemampuan untuk menghasilkan keuntungan neto sebesar $31,22 \%$. Ini berarti kemampuan dari modal yang diinvestasikan dalam keseluruhan aktiva untuk menghasilkan keuntungan neto sebesar Rp.0,31

$$
\begin{array}{rlr}
\text { Tahun } 2017 & =\frac{152.252 .375}{477.650 .500} \times 100 \% \\
\cdots & =31,87 \%
\end{array}
$$


Net earning power ratio merupakan kemampuan untuk menghasilkan keuntungan neto sebesar 31,87 \%. Ini berarti kemampuan dari modal yang diinvestasikan dalam keseluruhan aktiva untuk menghasilkan keuntungan neto sebesar Rp.0,32

$$
\begin{gathered}
\text { Tahun } 2018=\frac{155.648 .216}{495.150 .500} \times 100 \% \\
=\quad 31,43 \%
\end{gathered}
$$

Net earning power ratio merupakan kemampuan untuk menghasilkan keuntungan neto sebesar 31,43 \%. Ini berarti kemampuan dari modal yang diinvestasikan dalam keseluruhan aktiva untuk menghasilkan keuntungan neto sebesar Rp.0,31.

$$
\begin{array}{ll}
\text { Tahun } 2019= & \frac{164.500 .000}{499.750 .500} \\
\cdot & =32,91 \%
\end{array}
$$

Net earning power ratio merupakan kemampuan untuk menghasilkan keuntungan neto sebesar 32,91 \%. Ini berarti kemampuan dari modal yang diinvestasikan dalam keseluruhan aktiva untuk menghasilkan keuntungan neto sebesar Rp.0,33

\section{Tabel -6 \\ ROI}

\section{PT. Bukit Agung Sehati Palembang}

\begin{tabular}{|c|c|c|c|c|c|}
\hline Tahun & $\begin{array}{c}\text { Netto Sesudah } \\
\text { Pajak }\end{array}$ & Jumlah Aktiva & $\begin{array}{c}\text { Standar } \\
\text { Rasio }\end{array}$ & R O I & Hasil Penelitian \\
\hline 2015 & 150.252 .375 & 485.189 .123 & $30 \%$ & $30,96 \%$ & Tahun Dasar \\
\hline 2016 & 150.648 .216 & 482.494 .348 & $30 \%$ & $31,22 \%$ & Diatas Standar \\
\hline 2017 & 152.252 .375 & 477.650 .500 & $30 \%$ & $31,80 \%$ & Diatas Standar \\
\hline 2018 & 155.648 .216 & 495.150 .500 & $30 \%$ & $31,40 \%$ & Diatas Standar \\
\hline 2019 & 164.500 .000 & 499.750 .500 & $30 \%$ & $32,90 \%$ & Diatas Standar \\
\hline
\end{tabular}

Net Earning Power Ratio (ROI) untuk mengukur kemampuan dari modal yang diinvestasikan dalam keseluruhan aktiva untuk menghasilkan keuntungan netto pada tahun 2015 mencapai 30,96\% dan pada tahun 2016 mengalami kenaikan yaitu mencapai $31,22 \%$, dan pada tahun 2017 mengalami kenaikan 
juga sebesar $31,80 \%$, dan pada tahun 2018 mengalamai penurunan sebesar $31,40 \%$ dan tahun 2019 mencapai 32,90\% dari kelima tahun diatas dapat dilihat bahwa PT. Buli Agung Sehati Palembang untuk Net earning power ratio sudah diatas standar $30 \%$. ini berarti kemampuan modal menghasilkan keuntungan netto adalah baik.

\subsubsection{Return On Equity (ROE)}

Return on equity merupakan salah satu cara untuk mengukur profitabilitas suatu perusahaan. ROE adalah rasio profitabilitas yang mengukur kemampuan perusahaan dalam menghasilkan laba dari penggunaan modal perusahaan itu sendiri. Return On Equity (ROE) juga mencerminkan tingkat pengembalian atas ekuitas pemilik perusahaan. ROE (return on equity) dapat dihitung dengan rumus Dupont Formula, yang dipengaruhi tiga faktor, profitabilitas (profitability), efisiensi operasional (operational efficiency) dan utang (leverage).
Rumus :

$$
\text { ROE }=\text { Net Income / Equity }
$$

$$
\begin{aligned}
\text { Tahun } 2015 & =\frac{150 \cdot 252 \cdot 375}{885 \cdot 626 \cdot 790} \\
& =0,17
\end{aligned}
$$

Tahun $2016=150.648216$ 838.130 .440

$$
=0,18
$$

$$
\begin{array}{ll}
\text { Tahun } 2017 & =\frac{152 \cdot 252.375}{821.755 .375 . \ldots} \\
. & =0,18
\end{array}
$$

$$
\begin{aligned}
\text { Tahun } 2018 & =\frac{155 \cdot 648 \cdot 216}{830 \cdot 494 \cdot 716} \\
& =0,18
\end{aligned}
$$

$\begin{aligned} \text { Tahun } 2019= & \frac{164.500 .000}{856.139 .108} \\ = & 0,19\end{aligned}$

Tabel -7

Return On Equity (ROE)

PT. Bukit Agung Sehati Palembang

\begin{tabular}{|c|c|c|c|c|}
\hline TAHUN & $\begin{array}{c}\text { Net } \\
\text { Income }\end{array}$ & Equity & ROE & Hasil Peneltian \\
\hline 2015 & 150.252 .375 & 885.626 .790 & 0,17 & Tahun Dasar \\
\hline 2016 & 150.648 .216 & 838.130 .440 & 0,18 & Meningkat \\
\hline 2017 & 152.252 .375 & 821.755 .375 & 0,18 & Tetap \\
\hline 2018 & 155.648 .216 & 830.494 .716 & 0,18 & Tetap \\
\hline 2019 & 164.500 .000 & 856.139 .108 & 0,19 & Meningkat \\
\hline
\end{tabular}

Sumber : Diolah dari Neraca dan Laporan Laba Rugi PT. Bukit Agung Sehati Pal e mbang 
Berdasarkan perhitungan diatas terlihat bahwa untuk tahun 2015 setiap rupiah modal kerja perusahaan akan menghasilkan laba sebesar Rp. 0,17 dan pada tahun 2016 setiap rupiah modal kerja perusahaan akan menghasilkan kenaika laba sebesar Rp. 0,18 serta pada tahun 2017 setiap rupiah modal kerja perusahaan mengalami kenaikan sebesar Rp. 0,18. Pada tahun 2018 setiap rupiah modal kerja perusahaan mengalami kenaikan kembali dengan menghasilkan laba Rp. 0,18 dan pada tahun 2019 mengalami peningkatan sebesar 0,19.

\subsubsection{Teknik Analisis Data}

\subsubsection{Uji Regresi Linier Sederhana}

Analisis regresi linier sederhana bertujuan untuk mengetahui bagaimana pengaruh variabel indenpenden terhadap variabel dependent. Untuk mengetahui kuat lemahnya pengaruh dari modal kerja terhadap rentabilitas dapat dilihat dari koefisien regrfesi. Adapun hasil analisis regrfesi linier sederhana sebagai berikut :

Tabel -8

Hasil Uji Regresi Linier Sederhana Antara Cash Ratio Terhadap ROI Coefficients $^{\mathrm{a}}$

\begin{tabular}{|c|c|c|c|c|c|}
\hline \multirow[t]{2}{*}{ Model } & \multicolumn{2}{|c|}{ Unstandardized Coefficients } & \multirow{2}{*}{$\begin{array}{c}\text { Standardized } \\
\text { Coefficients } \\
\text { Beta }\end{array}$} & \multirow[t]{2}{*}{$\mathrm{t}$} & \multirow[t]{2}{*}{ Sig. } \\
\hline & B & Std. Error & & & \\
\hline (Constant) & ,315 &, 110 & & 2,874 &, 064 \\
\hline 1 CASH RATIO & 019 &, 017 & ,543 & 1,120 & ,344 \\
\hline
\end{tabular}

a. Dependent Variable: ROI

Sumber : pengolahan data primer dengan SPSS 22

Dari hasil perhitungan tabel 4.8 maka dapat dibentuk persamaan regresi yaitu : $Y=0,315+0,019 X$

TABEL 9

Hasil Uji Regresi Linier Sederhana Antara Cash Ratio Terhadap ROE Coefficients $^{\mathrm{a}}$

\begin{tabular}{|c|c|c|c|c|c|}
\hline \multirow[t]{2}{*}{ Model } & \multicolumn{2}{|c|}{ Unstandardized Coefficients } & \multirow{2}{*}{$\begin{array}{c}\text { Standardized } \\
\text { Coefficients } \\
\text { Beta }\end{array}$} & \multirow[t]{2}{*}{$\mathrm{t}$} & \multirow[t]{2}{*}{ Sig. } \\
\hline & $\mathrm{B}$ & Std. Error & & & \\
\hline (Constant) & ,333 &, 115 & & 2,903 &, 062 \\
\hline 1 CASH RATIO & 018 & ,018 &, 507 & 1,019 & ,383 \\
\hline
\end{tabular}

a. Dependent Variable: ROE

Sumber : pengolahan data primer dengan SPSS 22

Dari hasil perhitungan tabel 4.9 maka dapat dibentuk persamaan regresi yaitu $\mathbf{Y}=\mathbf{0 , 3 3 3}+\mathbf{0 , 0 1 8 X}$ 
Tabel -10

Hasil Uji Regresi Linier Sederhana Antara Cash Ratio Terhadap NPM

Coefficients $^{\mathrm{a}}$

\begin{tabular}{|c|c|c|c|c|c|}
\hline \multirow[t]{2}{*}{ Model } & \multicolumn{2}{|c|}{ Unstandardized Coefficients } & \multirow{2}{*}{$\begin{array}{c}\text { Standardized } \\
\text { Coefficients } \\
\text { Beta }\end{array}$} & \multirow[t]{2}{*}{$\mathrm{t}$} & \multirow[t]{2}{*}{ Sig. } \\
\hline & B & Std. Error & & & \\
\hline (Constant) &, 539 & ,058 & & 9,326 & ,003 \\
\hline 1 CASH RATIO &,- 012 & ,009 &,- 627 & $-1,392$ & ,258 \\
\hline
\end{tabular}

a. Dependent Variable: NPM

Sumber : pengolahan data primer dengan SPSS 22

Dari hasil perhitungan tabel 4.10 maka dapat dibentuk persamaan regresi yaitu

$$
Y=0,539+-0,012 X
$$

TABEL 11

Hasil Uji Regresi Linier Sederhana Antara Current Ratio Terhadap ROI

Coefficients $^{\mathrm{a}}$

\begin{tabular}{|c|c|c|c|c|c|}
\hline \multirow[t]{2}{*}{ Model } & \multicolumn{2}{|c|}{ Unstandardized Coefficients } & \multirow{2}{*}{$\begin{array}{c}\text { Standardized } \\
\text { Coefficients } \\
\text { Beta }\end{array}$} & \multirow[t]{2}{*}{$\mathrm{t}$} & \multirow[t]{2}{*}{ Sig. } \\
\hline & B & Std. Error & & & \\
\hline (Constant) & ,338 & 137 & & 2,463 & 091 \\
\hline $\begin{array}{ll} & \text { CURRENT } \\
1 & \text { RATIO }\end{array}$ & ,006 & ,009 & ,382 & ,715 &, 526 \\
\hline
\end{tabular}

a. Dependent Variable: ROI

Sumber : pengolahan data primer dengan SPSS 22

Dari hasil perhitungan tabel 4.11 maka dapat dibentuk persamaan regresi yaitu

$\mathrm{Y}=\mathbf{0 , 3 3 8}+\mathbf{0 , 0 0 6} \mathrm{X}$

Tabel -12

Hasil Uji Regresi Linier Sederhana Antara Current Ratio Terhadap ROE Coefficients $^{\mathrm{a}}$

\begin{tabular}{|c|c|c|c|c|c|}
\hline \multirow[t]{2}{*}{ Model } & \multicolumn{2}{|c|}{ Unstandardized Coefficients } & \multirow{2}{*}{$\begin{array}{c}\text { Standardized } \\
\text { Coefficients } \\
\text { Beta }\end{array}$} & \multirow[t]{2}{*}{$\mathrm{t}$} & \multirow[t]{2}{*}{ Sig. } \\
\hline & B & Std. Error & & & \\
\hline (Constant) & 359 &, 142 & & 2,521 & ,086 \\
\hline $\begin{array}{ll} & \text { CURRENT } \\
1 & \text { RATIO }\end{array}$ &, 006 & ,009 & ,341 & ,628 &, 574 \\
\hline
\end{tabular}

a. Dependent Variable: ROE

Sumber : pengolahan data primer dengan SPSS 22

Dari hasil perhitungan tabel 4.12 maka dapat dibentuk persamaan regresi yaitu 
$Y=0,359+\mathbf{0 , 0 0 6 X}$

Tabel 13

Hasil Uji Regresi Linier Sederhana Antara Current Terhadap NPM

Coefficients $^{\mathrm{a}}$

\begin{tabular}{|c|c|c|c|c|c|}
\hline \multirow[t]{2}{*}{ Model } & \multicolumn{2}{|c|}{ Unstandardized Coefficients } & \multirow{2}{*}{$\begin{array}{c}\text { Standardized } \\
\text { Coefficients } \\
\text { Beta } \\
\end{array}$} & \multirow[t]{2}{*}{$\mathrm{t}$} & \multirow[t]{2}{*}{ Sig. } \\
\hline & B & Std. Error & & & \\
\hline (Constant) & ,539 &, 071 & & 7,636 & 005 \\
\hline $\begin{array}{ll} & \text { CURRENT } \\
1 & \text { RATIO }\end{array}$ &,- 005 &, 004 &,- 546 & $-1,128$ &, 341 \\
\hline
\end{tabular}

a. Dependent Variable: NPM

Sumber : pengolahan data primer dengan SPSS 22

Dari hasil perhitungan tabel 4.8 maka dapat dibentuk persamaan regresi yaitu $\mathrm{Y}=\mathbf{0 , 5 3 9 + - 0 , 0 0 5 X}$

Tabel -14

Hasil Uji Regresi Linier Sederhana Antara WCTA Terhadap ROI Coefficients $^{\mathrm{a}}$

\begin{tabular}{|c|c|c|c|c|c|}
\hline \multirow[t]{2}{*}{ Model } & \multicolumn{2}{|c|}{ Unstandardized Coefficients } & \multirow{2}{*}{$\begin{array}{c}\text { Standardized } \\
\text { Coefficients } \\
\text { Beta }\end{array}$} & \multirow[t]{2}{*}{$\mathrm{t}$} & \multirow[t]{2}{*}{ Sig. } \\
\hline & B & Std. Error & & & \\
\hline (Constant) &,- 024 & ,322 & & $-0,74$ & ,946 \\
\hline 1 WCTA & 1,171 & ,824 & ,634 & 1,420 & ,251 \\
\hline
\end{tabular}

a. Dependent Variable: ROI

Sumber : pengolahan data primer dengan SPSS 22

Dari hasil perhitungan tabel 4.9 maka dapat dibentuk persamaan regresi yaitu $Y=-0,024+1,171 X$

Tabel -15

Hasil Uji Regresi Linier Sederhana Antara WCTA Terhadap ROE Coefficients $^{\mathrm{a}}$

\begin{tabular}{|c|c|c|c|c|c|}
\hline \multirow[t]{2}{*}{ Model } & \multicolumn{2}{|c|}{ Unstandardized Coefficients } & \multirow{2}{*}{$\begin{array}{c}\text { Standardized } \\
\text { Coefficients } \\
\text { Beta }\end{array}$} & \multirow[t]{2}{*}{$\mathrm{t}$} & \multirow[t]{2}{*}{ Sig. } \\
\hline & B & Std. Error & & & \\
\hline (Constant) &,- 022 & ,328 & & $-0,69$ & ,950 \\
\hline 1 WCTA & 1,200 & ,839 & ,637 & 1,430 & ,248 \\
\hline
\end{tabular}

a. Dependent Variable: ROE

Sumber : pengolahan data primer dengan SPSS 22

Dari hasil perhitungan tabel 4.8 maka dapat dibentuk persamaan regresi yaitu 


$$
Y=-\mathbf{0 , 0 2 2 + 1 , 2 0 0 X}
$$

\section{Tabel -16}

Hasil Uji Regresi Linier Sederhana Antara WCTA Terhadap NPM

Coefficients $^{\mathrm{a}}$

\begin{tabular}{|c|c|c|c|c|c|}
\hline \multirow[t]{2}{*}{ Model } & \multicolumn{2}{|c|}{ Unstandardized Coefficients } & \multirow{2}{*}{$\begin{array}{c}\text { Standardized } \\
\text { Coefficients } \\
\text { Beta } \\
\end{array}$} & \multirow[t]{2}{*}{$\mathrm{t}$} & \multirow[t]{2}{*}{ Sig. } \\
\hline & $\mathrm{B}$ & Std. Error & & & \\
\hline (Constant) & 679 & ,207 & & 3,384 & ,043 \\
\hline 1 WCTA &,- 557 &, 513 &,- 531 & $-1,086$ & ,357 \\
\hline
\end{tabular}

a. Dependent Variable: NPM

Sumber : pengolahan data primer dengan SPSS 22

Dari hasil perhitungan tabel 4.11 maka dapat dibentuk persamaan regresi yaitu

$$
\mathrm{Y}=\mathbf{0 , 6 7 9 + - 0 , 5 5 7 X}
$$

\subsubsection{Uji Parsial (Uji t)}

Pengujian ini dilakukan untuk mengetahui signifikan peran secara parsial atau sendirisendiri antara variabel indenpenden terhaddap variabel dependen dengan mengasumsikan bahwa vaiabel indenpenden lain dianggap konstan.

Hipotesis penelitian ini adalah :

- Ho : $\beta=0$ : tidak terdapat pengaruh yang signifikan

- Ho: $\beta \neq 0$ : terapat pengaruh yang signifikan

Dengan kriteria yang dapat digunakan sebagai berikut :

- Ho diterima jika nilai $\mathrm{t}_{\text {hitung }} \leq \mathrm{t}_{\text {tabel }}$ atau nilai sig $>\alpha$

- Ho ditolak jika nilai $\mathrm{t}_{\text {hitung }} \geq \mathrm{t}_{\text {tabel }}$ atau nilai sig $<\alpha$

- level signifikansi $(\alpha)$ dengan nilai $\alpha=0,05$

Sedangkan untuk melihat besarnya penagruh digunakan angka Beta atau standardized Coefficient dibawah ini :

\section{Tabel -17}

\section{Hasil Uji Parsial (Uji-t) Antara Cash Ratio Terhadap ROI}

\begin{tabular}{|c|c|c|c|c|c|}
\hline \multirow[t]{2}{*}{ Model } & \multicolumn{2}{|c|}{ Unstandardized Coefficients } & \multirow{2}{*}{$\begin{array}{c}\text { Standardized } \\
\text { Coefficients } \\
\text { Beta }\end{array}$} & \multirow[t]{2}{*}{$\mathrm{t}$} & \multirow[t]{2}{*}{ Sig. } \\
\hline & $\mathrm{B}$ & Std. Error & & & \\
\hline (Constant) &, 315 &, 110 & & 2,874 &, 064 \\
\hline 1 CASH RATIO & ,019 &, 017 &, 543 & 1,120 & ,344 \\
\hline
\end{tabular}

\section{Coefficients $^{\mathrm{a}}$}

a. Dependent Variable: ROI

Hasil Uji-t dapat dijelaskan bahwa nilai t hitung untuk varibael Casg Ratio (X1) sebesar 1,120 dan nilai signifikansinya (sig) sebesar 0,344. Nilai signifikan tersebut lebih besar 
daari 0,05. Berarti bisa disimpulkan bahwa data tersebut bersifat positif dan juga menunjukkan bahwa tidak berpengaruh secara signifikan antara Cash Ratio (X1) dengan ROI (Y1).

\section{Tabel -18}

\section{Hasil Uji Parsial (Uji-t) Antara Cash Ratio Terhadap ROE}

Coefficients $^{\mathrm{a}}$

\begin{tabular}{|c|c|c|c|c|c|}
\hline \multirow[t]{2}{*}{ Model } & \multicolumn{2}{|c|}{ Unstandardized Coefficients } & \multirow{2}{*}{$\begin{array}{c}\text { Standardized } \\
\text { Coefficients } \\
\text { Beta }\end{array}$} & \multirow[t]{2}{*}{$\mathrm{t}$} & \multirow[t]{2}{*}{ Sig. } \\
\hline & B & Std. Error & & & \\
\hline (Constant) & ,333 &, 115 & & 2,903 &, 062 \\
\hline 1 CASH RATIO & ,018 &, 018 & ,507 & 1,019 & ,383 \\
\hline
\end{tabular}

Hasil Uji-t dapat dijelaskan bahwa nilai t hitung untuk variabel Cash Ratio (X1) sebesar 1,019 dan nilai signifikansinya (sig) sebesar 0,383 . Nilai signifikan tersebut lebih besar dari 0,05. Berarti bisa disimpulkan bahwa data tersebut bersifat positif dan juga menunjukkan bahwa tidak berpengaruh secara signifikan antara Cash Ratio (X1) dengan ROE (Y2).

\section{Tabel -19}

Hasil Uji Parsial (Uji-t) Antara Cash Ratio Terhadap NPM

\begin{tabular}{|c|c|c|c|c|c|}
\hline \multicolumn{6}{|c|}{ Coefficients $^{\mathrm{a}}$} \\
\hline \multirow[t]{2}{*}{ Model } & \multicolumn{2}{|c|}{ Unstandardized Coefficients } & \multirow{2}{*}{$\begin{array}{c}\text { Standardized } \\
\text { Coefficients } \\
\text { Beta }\end{array}$} & \multirow[t]{2}{*}{$\mathrm{t}$} & \multirow[t]{2}{*}{ Sig. } \\
\hline & $\mathrm{B}$ & Std. Error & & & \\
\hline (Constant) &, 539 &, 058 & & 9,326 & ,003 \\
\hline 1 CASH RATIO &,- 012 & 009 &,- 627 & $-1,392$ & ,258 \\
\hline
\end{tabular}

Hasil Uji-t dapat dijelaskan bahwa nilai t hitung untuk variabel Cash Ratio (X1) sebesar 1,392 dan nilai signifikansinya (sig) sebesar 0,258. Nilai signifikan tersebut lebih besar dari 0,05. Berarti bisa disimpulkan bahwa data tersebut bersifat positif dan juga menunjukkan bahwa tidak berpengaruh secara signifikan antara Cash Ratio (X1) dengan NPM (Y3).

Tabel -20

\section{Hasil Uji Parsial (Uji-t) Antara Current Ratio Terhadap ROI}

\section{Coefficients $^{\mathrm{a}}$}

\begin{tabular}{|c|c|c|c|c|c|}
\hline \multirow[t]{2}{*}{ Model } & \multicolumn{2}{|c|}{ Unstandardized Coefficients } & \multirow{2}{*}{$\begin{array}{c}\text { Standardized } \\
\text { Coefficients } \\
\text { Beta }\end{array}$} & \multirow[t]{2}{*}{$\mathrm{t}$} & \multirow[t]{2}{*}{ Sig. } \\
\hline & B & Std. Error & & & \\
\hline (Constant) & ,338 & 137 & & 2,463 & 091 \\
\hline $\begin{array}{ll} & \text { CURRENT } \\
1 & \text { RATIO }\end{array}$ & ,006 & ,009 & ,382 & ,715 &, 526 \\
\hline
\end{tabular}


a. Dependent Variable: ROI

Sumber : pengolahan data primer dengan SPSS 22

Hasil Uji-t dapat dijelaskan bahwa nilai t hitung untuk variabel Current Ratio (X2) sebesar 0,715 dan nilai signifikansinya (sig) sebesar 0,526. Nilai signifikan tersebut lebih besar dari 0,05. Berarti bisa disimpulkan bahwa data tersebut bersifat positif dan juga menunjukkan bahwa tidak berpengaruh secara signifikan antara Current Ratio (X2) dengan ROI (Y2).

\section{Tabel -21 \\ Hasil Uji Parsial (Uji-t) Antara Current Ratio Terhadap ROE Coefficients $^{\mathrm{a}}$}

\begin{tabular}{|c|c|c|c|c|c|}
\hline \multirow[t]{2}{*}{ Model } & \multicolumn{2}{|c|}{ Unstandardized Coefficients } & \multirow{2}{*}{$\begin{array}{c}\text { Standardized } \\
\text { Coefficients } \\
\text { Beta }\end{array}$} & \multirow[t]{2}{*}{$\mathrm{t}$} & \multirow[t]{2}{*}{ Sig. } \\
\hline & $\mathrm{B}$ & Std. Error & & & \\
\hline (Constant) & ,359 & , 142 & & 2,521 & ,086 \\
\hline $\begin{array}{ll} & \text { CURRENT } \\
1 & \text { RATIO }\end{array}$ & ,006 & ,009 & ,341 & ,628 & ,574 \\
\hline
\end{tabular}

a. Dependent Variable: ROE

Hasil Uji-t dapat dijelaskan bahwa nilai t hitung untuk variabel Current Ratio (X2) sebesar 0,628 dan nilai signifikansinya (sig) sebesar 0,574. Nilai signifikan tersebut lebih besar dari 0,05. Berarti bisa disimpulkan bahwa data tersebut bersifat positif dan juga menunjukkan bahwa tidak berpengaruh secara signifikan antara Current Ratio (X2) dengan ROE (Y2).

Tabel -22

Hasil Uji Parsial (Uji-t) Antara Current Ratio Terhadap NPM Coefficients $^{\mathbf{a}}$

\begin{tabular}{|c|c|c|c|c|c|}
\hline \multirow[t]{2}{*}{ Model } & \multicolumn{2}{|c|}{ Unstandardized Coefficients } & \multirow{2}{*}{$\begin{array}{c}\text { Standardized } \\
\text { Coefficients } \\
\text { Beta }\end{array}$} & \multirow[t]{2}{*}{$\mathrm{t}$} & \multirow[t]{2}{*}{ Sig. } \\
\hline & $\mathrm{B}$ & Std. Error & & & \\
\hline (Constant) &, 539 &, 071 & & 7,636 & 005 \\
\hline $\begin{array}{ll} & \text { CURRENT } \\
1 & \text { RATIO }\end{array}$ &,- 005 &, 004 &,- 546 & $-1,128$ &, 341 \\
\hline
\end{tabular}

a. Dependent Variable: NPM

Hasil Uji-t dapat dijelaskan bahwa nilai t hitung untuk variabel Current Ratio (X3) sebesar 0,628 dan nilai signifikansinya (sig) sebesar 0,574. Nilai signifikan tersebut lebih besar dari 0,05. Berarti bisa disimpulkan bahwa data tersebut bersifat positif dan juga menunjukkan bahwa tidak berpengaruh secara signifikan antara Current Ratio (X3) dengan NPM 
(Y3).

Tabel -23

Hasil Uji Parsial (Uji-t) Antara WCTA Terhadap ROI Coefficients $^{\mathrm{a}}$

\begin{tabular}{|c|c|c|c|c|c|}
\hline \multirow[t]{2}{*}{ Model } & \multicolumn{2}{|c|}{ Unstandardized Coefficients } & \multirow{2}{*}{$\begin{array}{c}\text { Standardized } \\
\text { Coefficients } \\
\text { Beta }\end{array}$} & \multirow[t]{2}{*}{$\mathrm{t}$} & \multirow[t]{2}{*}{ Sig } \\
\hline & B & Std. Error & & & \\
\hline (Constant) &,- 024 &, 322 & & $-0,74$ & ,946 \\
\hline 1 WCTA & 1,171 &, 824 & ,634 & 1,420 & ,251 \\
\hline
\end{tabular}

a. Dependent Variable: ROI

Hasil Uji-t dapat dijelaskan bahwa nilai t hitung untuk variabel WCTA (X3) sebesar 1,420 dan nilai signifikansinya (sig) sebesar 0,251. Nilai signifikan tersebut lebih besar dari 0,05. Berarti bisa disimpulkan bahwa data tersebut bersifat positif dan juga menunjukkan bahwa tidak berpengaruh secara signifikan antara WCTA (X3) dengan ROI (Y3).

Tabel -24

Hasil Uji Parsial Antara WCTA Terhadap ROE

Coefficients $^{\mathrm{a}}$

\begin{tabular}{|c|c|c|c|c|c|}
\hline \multirow[t]{2}{*}{ Model } & \multicolumn{2}{|c|}{ Unstandardized Coefficients } & \multirow{2}{*}{$\begin{array}{c}\text { Standardized } \\
\text { Coefficients } \\
\text { Beta }\end{array}$} & \multirow[t]{2}{*}{$\mathrm{t}$} & \multirow[t]{2}{*}{ Sig. } \\
\hline & $\mathrm{B}$ & Std. Error & & & \\
\hline (Constant) &,- 022 & ,328 & & $-0,69$ & ,950 \\
\hline 1 WCTA & 1,200 & 839 & ,637 & 1,430 & ,248 \\
\hline
\end{tabular}

a. Dependent Variable: ROE

Hasil Uji-t dapat dijelaskan bahwa nilai t hitung untuk variabel WCTA (X3) sebesar 1,430 dan nilai signifikansinya (sig) sebesar 0,248. Nilai signifikan tersebut lebih besar dari 0,05. Berarti bisa disimpulkan bahwa data tersebut bersifat positif dan juga menunjukkan bahwa tidak berpengaruh secara signifikan antara WCTA (X3) dengan ROI (Y3).

\section{Tabel -25}

\section{Hasil Uji Parsial Antara WCTA Terhadap NPM}

Coefficients $^{\mathrm{a}}$

\begin{tabular}{|c|c|c|c|c|c|}
\hline \multirow[t]{2}{*}{ Model } & \multicolumn{2}{|c|}{ Unstandardized Coefficients } & \multirow{2}{*}{$\begin{array}{c}\text { Standardized } \\
\text { Coefficients } \\
\text { Beta }\end{array}$} & \multirow[t]{2}{*}{$\mathrm{t}$} & \multirow[t]{2}{*}{ Sig. } \\
\hline & B & Std. Error & & & \\
\hline (Constant) & 679 & 207 & & 3,384 & 043 \\
\hline 1 WCTA &,- 557 & ,513 &,- 531 & $-1,086$ & 357 \\
\hline
\end{tabular}

a. Dependent Variable: NPM 
Hasil Uji-t dapat dijelaskan bahwa nilai t hitung untuk variabel WCTA (X3) sebesar 1,086 dan nilai signifikansinya (sig) sebesar 0,357. Nilai signifikan tersebut lebih besar dari 0,05. Berarti bisa disimpulkan bahwa data tersebut bersifat positif dan juga menunjukkan bahwa tidak berpengaruh secara signifikan antara WCTA (X3) dengan NPM (Y3).

\subsection{Pembahasan}

Berdasarkan hasil penelitian analisis regresi linier sederhana antara Cash Ratio terhadap ROI yaitu $\mathrm{Y}=0,315+$ 0,019 X, Cash Ratio terhadap ROE yaitu $\mathrm{Y}=0,333+0,018 \mathrm{X}$, Cash Ratio terhadap NPM yaitu $Y=0,539+0,012 X$, Curren Ratio terhadap ROI $\mathrm{Y}=0,338+0,006 \mathrm{X}$, Current Ratio terhadap ROE $\mathrm{Y}=0,359+0,006 \mathrm{X}$, Current Ratio terhadap NPM Y=0,539 +0,005X,WCTA terhadap ROI $\mathrm{Y}=0,024+$ $1,171 \mathrm{X}$, WCTA terhadap ROE $\mathrm{Y}=-0,022$ $+1,200 X$, WCTA terhadap NPM Y= $0,679+-0,557 \mathrm{X}$.

Berdasarkan hasil penelitian analisis uji-t antara Cash Ratio terhadap ROI sebesar 1,120 dan nilai signifikannya (sig) sebesar 0,344. Nilai signifikan tersebut lebih besar ari 0,05. Berarti bisa disimpulkan bahwa data tersebut bersifat positif dan juga menunjukkan bahwa tidak berpengaruh secara signifikan. Cash Ratio terhadap ROE sebesar 1,019 dan nilai nsignifikannya (sig) sebesar 0,383. Nilai signifikan tersebut lebih besar dari 0,05. Berarti bisa disimpulkan bahwa data tersebut bersifat positif dan juga menunjukkan bahwa tidak berpengaruh secara signifikan. Cash Ratio terhadap NPM sebesar $-1,392$ dan nilai signifikansinya (sig) sebesar 0,258. Nilai signifikan tersebut lebih besar darin 0,05. Berarti bisa disimpulkan bahawa data tersebut bersifat negatif dan juga menunjukkan bahwa tidak berpengaruh secara signifikan. Current Ratio terhadap ROI sebear 0,715 dan nilai signifikansinya (sig) sebear 0,574. Nilai signifikan tersebut lebih besar dari 0,05. Berarti bisa disimpulkan bahwa data tersebut bersifat possitif dan juga menunjukkan bahwa tidak berpengaruh secara signifikan. Current Ratio terhadap ROE sebesar 0,628 dan nilai signifikansinya (sig) sebear 0,526. Nilai signifikan tersebut lebih besar dari 0,05 . Berarti bisa disimpulkan bahwa data tersebut bersifat possitif dan juga menunjukkan bahwa tidak berpengaruh secara signifikan. Currentb Ratio terhadap NPM sebesar $-1,128$ dan nilai signifikansinya (sig) sebesar 0,341. Nilai signifikan tersebut lebih besar dari 0,05. Berarti bisa disimpulkan bahwa data tersebut bersifat negatif dan juga menunjukkan bahwa tidak berpengaruh secara signifikan. WCTA terhadap ROI sebear 1,420 dan nilai signifikansinya (sig) sebear 0,251. Nilai signifikan tersebut lebih besar dari 0,05. Berarti bisa disimpulkan bahwa data tersebut bersifat possitif dan juga menunjukkan bahwa tidak berpengaruh secara signifikan. WCTA terhadap ROE sebear 1,430 dan nilai signifikansinya (sig) sebear 0,248. Nilai signifikan tersebut lebih besar dari 0,05. Berarti bisa disimpulkan bahwa data tersebut bersifat possitif dan juga menunjukkan bahwa tidak berpengaruh secara signifikan. WCTA terhadap NPM sebear -1,086 dan nilai signifikansinya (sig) sebear 0,357. Nilai signifikan tersebut lebih besar dari 0,05. Berarti bisa disimpulkan bahwa data tersebut bersifat possitif dan juga menunjukkan bahwa tidak berpengaruh secara signifikan.

\section{V.KESIMPULAN DAN SARAN}

\subsection{Kesimpulan}

Penelitian ini menguji Pengaruh 
Modal Kerja Terhadap Rentabilitas. Penelitian ini menguji enam variabel yang terdiri dari variabel $\mathrm{X}$ sebagai modal kerja yang terdiri dari Profit Margin, Operating Ratio dan Working Capital Total to Asset (WCTA). Dan untuk variabel Y sebagai rentabilitas yang terdiri dari Return On Investment (ROI), Return On Equity (ROE) dan Net Profit Margin (NPM).

Berdasarkan hasil analisis dan pengujian hipotesis dapat disimpulkan sebagai berikut :

1. Hasil penelitian analisis regresi linier sederhana beserta uji $\mathrm{t}$ didapati pengaruh sebagai berikut :

a. Hasil pengujian menunjukkan bahwa tidak berpengaruh secara signifikan antara Cash Ratuo (X1) dan ROI (Y1)

b. Hasil pengujian menunjukkan bahwa tidak berpengaruh secara signifikan antara Gross Profit Margin (X1) dan ROE (Y2)

c. Hasil pengujian menunjukkan bahwa tidak berpengaruh secara signifikan antara Cash Ratio (X1) dan NPM (Y3)

d. Hasil pengujian menunjukkan bahwa tidak berpengaruh secara signifikan antara Current Ratio (X2) dan ROI (Y1)

e. Hasil pengujian menunjukkan bahwa tidak berpengaruh secara signifikan antara Current Ratio (X2) dan ROE (Y2)

f. Hasil pengujian menunjukkan bahwa tidak berpengaruh secara signifikan antara Current Ratio (X2) dan NPM (Y3)

g. Hasil pengujian menunjukkan bahwa tidak berpengaruh secara signifikan antara WCTA (X3) dan ROI (Y1)

h. Hasil pengujian menunjukkan bahwa tidak berpengaruh secara signifikan antara WCTA (X3) dan ROI (Y2)

i. Hasil pengujian menunjukkan bahwa tidak berpengaruh secara signifikan antara WCTA (X3) dan ROI (Y3)

\subsection{Saran}

Adapun saran yang dapat penulis berikan pada PT. Bukit Agung Seha t i $\mathrm{P}$ a l e mbang adalah :

1. Bagi Perusahaan

a. Berdasarkan hasil penelitian diatas, rendahnya pengaruh antara modal kerja terhadap profitabilitas pada P T .

b. Berdasarkan hasil penelitian diatas, bervariatifnya hubungan antara modal kerja terhadap profitabilitas pada PT. B uki t A g u n g S e h a t i P a l e mbang menandakan bahwa adanya ketidak seimbangan, maka dari itu diharapkan pihak perusahaan dapat lebih memperhatikan komponenkomponen sehingga dapat terciptanya hubungan yang selaras atau positif

\section{Bagi Penelitian Selanjutnya}

Diharapkan dapat menggunakan penelitian ini untuk mengembangkan lebih lanjut dalam menganalisis penagruh dan hubungan, yaitu dengan menambah periode penelitian, mengganti penelitian dengan objek yang lain, serta menambah variabel lainnya sehingga dapat memperbaiki penelitian sebelumnya.

\section{DAFTAR PUSTAKA}

Ati Susanti, dengan judul " Pengaruh Perputaran Modal Kerja Terhadap Profitabilitas" Cetakan Kesembilan, 
Penerbit Cipta,Jakarta,2016

Ariyanto, Dasar-Dasar Modal Kerja, Cetakan Kesembilan, Penerbit Cipta,Jakarta,2010

Alwi, Syafarudin, Alat-alat Analisis dalam pembelanjaan, Yogyakarta, Andi offset, 2005

Bhaduri , Analisis Laporan Keuangan, Yogyakarta, Liberty, 2012

Djahidin , Peneltian tentang status obyek penelitian, 2015

Fahmi, Irham. 2014. Analisis Kinerja Keuangan. cet 3. Bandung : Alfabeta

Gitman. 2015. Analisis Multiva riate Lanjutan dengan Program SPSS. Badan Penerbit Universitas Diponegoro. Semarang.

Jumingan, 2016, Dasar-Dasar Modal Kerja, Cetakan Kesembilan, Penerbit Cipta,Jakarta,2016

Kasmir. 2018. Analisis Faktor-Faktor Yang Mem pengaruhi Ketepatan Waktu Penyam paian Laporan Keuangan. Simpo sium Nasional Akuntansi XI Ikatan Indonesia. H.1-22.

Munawir. Dasar-Dasar Modal Kerja, Jakarta,2016

Priainah dan Kusuma , Analisis Laporan Keuangan, Yogyakarta, Liberty, 2015.

Riyanto,Bambang,Dasar-dasar Pembelanjaan Perusahaan, Edisi ketujuh, Penerbit BPFE, Yogyakarta,2016

Rizal Rizaludin , "Pengaruh Modal Kerja Terhadap Sisa Hasil Usaha”,2017

Sudana, I Made. (2015). "Manajemen Keuangan Perusahaan".Edisi Kedua. Jakarta: Erlangga

Sugiyono. (2016). “Metode Penelitian
Kuantitatif Kualitatif Dan R\&B." Bandung: Alfabeta.

Supriyadi dan Fazriani, 2015, "Pengaruh Modal kerja Tehadap Likuiditas dan profitabilitas pada PT. Timah Tbk"
Sutrisno,2018, "Analisa Laporan Keuangan", Cet.15. Liberty, Yogyakarta

Tunggal, Dasar-Dasar Modal Kerja, Jakarta,2015

Van Horne, Analisis Laporan Keuangan, Yogyakarta, 2016 